\title{
Effect of Oxidative Stress on Physicochemical Quality of Taiwanese Seagrape (Caulerpa lentillifera) with the Application of Alternating Current Electric Field (ACEF) during Post-Harvest Storage
}

\author{
Andi Syahrullah Sulaimana ${ }^{1}{ }^{10}$, Chao-Kai Chang ${ }^{2}$, Chih-Yao Hou ${ }^{3}{ }^{\circledR}$, Bara Yudhistira ${ }^{4,5}$, Fuangfah Punthi ${ }^{4}$, \\ Chun-Ta Lung ${ }^{4}$, Kuan-Chen Cheng ${ }^{6,7,8,9}$, Shella Permatasari Santoso ${ }^{10,11}$ and Chang-Wei Hsieh ${ }^{4,8, *(1)}$
}

check for

updates

Citation: Sulaimana, A.S.; Chang,

C.-K.; Hou, C.-Y.; Yudhistira, B.;

Punthi, F.; Lung, C.-T.; Cheng, K.-C.; Santoso, S.P.; Hsieh, C.-W. Effect of

Oxidative Stress on Physicochemical

Quality of Taiwanese Seagrape

(Caulerpa lentillifera) with the

Application of Alternating Current

Electric Field (ACEF) during

Post-Harvest Storage. Processes 2021,

9, 1011. https://doi.org/10.3390/

pr9061011

Academic Editor: Timothy Langrish

Received: 13 May 2021

Accepted: 3 June 2021

Published: 7 June 2021

Publisher's Note: MDPI stays neutral with regard to jurisdictional claims in published maps and institutional affiliations.

Copyright: (c) 2021 by the authors. Licensee MDPI, Basel, Switzerland. This article is an open access article distributed under the terms and conditions of the Creative Commons Attribution (CC BY) license (https:/ / creativecommons.org/licenses/by/ $4.0 /)$.
1 Department of International Master Program of Agriculture, National Chung Hsing University, 145 Xingda Road, South District, Taichung City 40227, Taiwan; andisyahrullah@smail.nchu.edu.tw

2 College of Biotechnology and Bioresources, Da-Yeh University, 168 University, Xuefu Road, Dacun Township, Changhua City 51591, Taiwan; kai0913077636@gmail.com

3 Department of Seafood Science, National Kaohsiung University of Science and Technology, 142 Haizhuan Road, Nanzi District., Kaohsiung City 81157, Taiwan; chihyaohou@gmail.com

4 Department of Food Science and Biotechnology, National Chung Hsing University, 145 Xingda Road, South District, Taichung City 40227, Taiwan; barayudhistira@staff.uns.ac.id (B.Y.); fuangfahp3@gmail.com (F.P.); as920227@gmail.com (C.-T.L.)

5 Department of Food Science and Technology, Sebelas Maret University, 36 Ir. Sutami Road, Surakarta City 57126, Indonesia

6 Graduate Institute of Food Science Technology, National Taiwan University, No. 1, Sec. 4, Roosevelt Road, Taipei 10617, Taiwan; kccheng@ntu.edu.tw

7 Institute of Biotechnology, National Taiwan University, 1, Sec 4, Roosevelt Road, Taipei 10617, Taiwan

8 Department of Medical Research, China Medical University Hospital, 91 Xueshi Road, North District, Taichung City 40402, Taiwan

9 Department of Optometry, Asia University, 500 Lioufeng Road, Wufeng, Taichung 41354, Taiwan

10 Department of Chemical Engineering, Widya Mandala Surabaya Catholic University, Kalijudan 37, Surabaya 60114, Indonesia; shella@ukwms.ac.id

11 Department of Chemical Engineering, National Taiwan University of Science and Technology, Keelung Rd. 43, Daan District, Taipei 10607, Taiwan

* Correspondence: welson@nchu.edu.tw; Tel.: +886-4-22840385 (ext. 5010); Fax: +886-4-22876211

\begin{abstract}
This study aims to determine the physicochemical quality of seagrape (Caulerpa lentillifera) as a freshness label for products cultivated in different seasons. The applied post-harvest storage experiments compared between, within and without seawater that led to oxidative stress conditions. Water content, malondialdehyde (MDA) compound, total phenolic content (TPC), and chlorophyll content were observed at $0,3,6$, and 9 days of storage. The storage without seawater showed sharper quality reductions by reaching $20-40 \%$ of water loss, $70-90 \%$ of MDA production, $15-25 \%$ of TPC reduction, and $40-60 \%$ of total chlorophyll degradation. The storage within seawater showed lower quality reductions due to the specific growth rates still reaching $5-10 \%$. This study found that the greater the physicochemical quality, the slower the decomposition rates of the stored seagrape during storage. Therefore, the seagrapes' obvious discoloration occurred earlier in winter, followed by summer and spring. Kinetics of chlorophyll degradation on seagrape in different seasons meet different order-reactions during storage. Furthermore, alternating current electric field (ACEF) treatment with $125 \mathrm{kV} / \mathrm{m}$ of intensity for $60 \mathrm{~min}$ can lower the spring seagrapes' physicochemical quality by reaching 10-30\% of inhibition, resulting in the shelf-life extension for up to 12 days of post-harvest storage.
\end{abstract}

Keywords: ACEF treatment; chlorophyll degradation; physicochemical quality; postharvest storage; seagrape Caulerpa lentillifera 


\section{Introduction}

Seagrape (Caulerpa lentillifera, C. lentillifera) is a species of green algae that is mostly cultivated and commercialized in Asia, especially in the temperate region [1]. Fresh seagrape is a product that has been exported to domestic and international markets due to its high nutritional value when consumed in society [2]. The thallus freshness, bright green color, and compact texture indicate the turgor pressure quality in the seagrape cell wall is still good. Since seagrapes' commercial activity need shipping and storage during its delivery process, thus proper packaging and preservation treatment is required to maintain its quality freshness. Seagrape is perishable after harvesting due to it containing more than $90 \%$ of water [3], thus it requires immediate post-harvest handling to keep its quality freshness. Several prototypes of packaging to store the fresh seagrape products have been described, but these only can maintain their shelf-life and quality less than a week $[1,2,4]$. This phenomenon is caused by the occurrence of the desiccation effect on seagrape after harvested due to the improper environment, which leads to oxidative stress conditions [5-7].

Seagrape is sensitive to osmotic pressure and low temperature and, in particular, it is easily damaged if stored in cold storage and tap water [8]. Hence, the current preservation methods that have been applied to seagrape are mostly the conventional processed technology such as drying and brining $[9,10]$. Djaeni and Sari [11] reported industrial drying of seagrape was usually performed at a heat air dryer about $50-80^{\circ} \mathrm{C}$ for around $12 \mathrm{~h}$. However, it was shown that the energy consumption increases exponentially as the drying temperature rises [9]. On the other hand, the brining method to produce salted seagrape is a process using high concentration of chemical compound [12]. Moreover, those methods are considered as creating a processed product, which is far from the market interest demanding this commodity in the fresh product form (salad) to gain more nutritional value [1].

Alternating current electric field (ACEF) technology is non-chemical low energy processing to maintain a commodity's freshness for a long shelf-life by interfering with its physiological, microbiological, and enzymatic activities [13]. Muthukumaran et al. [14] claimed the increased quality and decreased operating costs can be easily attained by this treatment, and this treatment is also applicable to any high-sensitive food products. Our previous studies showed the application of electric field (EF) in maintaining the physicochemical properties as well as extending the shelf-life of different food products (juice, fruit, vegetable, and meat) during storage [15-18]. However, the structure and physiological metabolism of seagrape following harvesting are distinct from those products. Additionally, the electric field effect is different for each agricultural product due to the differences in bio-conductivity including the cell structure and water content. Moreover, the influence of electric fields on physicochemical properties in the harvested macroalgae is rarely discussed.

Previous studies explained the environmental conditions (including seasonal temperature) that influence the normal growth of seagrape $[19,20]$. Since seagrape grows well in tropical countries year-round [1], this study aims to observe the physicochemical quality of seagrape in a sub-tropical country that has different seasons. Moreover, the post-harvest study related to the shelf-life factor of seagrape is rarely found. Therefore, this study also aims to apply an ACEF treatment to examine its impact in preserving the physicochemical quality and extending the shelf-life of seagrape during post-harvest storage. This study is expected to improve the consumer perspective and seagrape market acceptance.

\section{Materials and Methods}

\subsection{Materials}

Fresh samples of seagrape ( $150 \pm 10 \mathrm{~g})$ in different seasons [Spring (March-June) with the average temperature of $20-30{ }^{\circ} \mathrm{C}$; Summer (July-October) with the average temperature of $>30^{\circ} \mathrm{C}$; and Winter (November-February) with the average temperature of $<20^{\circ} \mathrm{C}$ ] were purchased from a seagrape farmer (Heshu Food Company Ltd., Pingtung, Taiwan). 
The samples were stored in a plastic bag within seawater and packed inside a polystyrene box. The harvested seagrape needs to be purified immediately inside a pool with seawater circulation for $24 \mathrm{~h}$ that aims to recover the wounded-thalli after harvested. Furthermore, the samples need $24 \mathrm{~h}$ of shipping time (at $27 \pm 0.8^{\circ} \mathrm{C}$ ) to Bioproduct Development Laboratory at National Chung Hsing University (Taichung City, Taiwan). All chemical compounds used in this study were analytical standard as follows: acetone solution (Choneye, Taiwan), thiobarbituric acid (TBA) (Panreac, Spain), trichloroacetic acid (TCA) (Daejung, Korea), Folin-Ciocalteau phenol reagent (Panreac, Spain), and sodium carbonate $\left(\mathrm{Na}_{2} \mathrm{CO}_{3}\right)$ (Katayama, Japan), and gallic acid (Scharlab, Spain).

\subsection{Sample Preparation and Packaging}

The samples were divided into two groups as follows; the storage within seawater (around $80 \mathrm{~mL}$ of seawater), and the storage without seawater (modified container). The sample group without seawater were dried from its seawater attachment with clean absorbent sheets without any pressure. About $5 \mathrm{~g}$ fresh branch was put into the modified container and the seawater storage (Figure 1). The modified container was a transparent polystyrene container (volume $5 \times 5 \times 5 \mathrm{~cm}^{3}$, thickness $0.1 \mathrm{~cm}$ ) consisting of a wet absorbent sheet from $100 \%$ of virgin wood pulp (Cheng Loong Corp., Taiwan) poured with $5 \mathrm{~mL}$ seawater and a dry holed polymer pad. According to Terada et al. [7], the wet absorbent layer aims to maintain the relative humidity $( \pm \mathrm{RH} 90 \%)$ of the container during storage time, and the dry holed layer aims to prevent harvested seagrape C. lentillifera from direct contact with the wet layer while experiencing the humidity. Paull and Chen [21] also proposed a packaging type with minimum gas exchange rates to keep the physical quality of the harvested seaweed Gracilaria salicornia during post-harvest storage. Therefore, the containers were shielded with the tape to avoid the free air exchange. The samples were stored for nine days and examined triplicate to study the oxidative stress effect during post-harvest storage. The quality indicators (malondialdehyde (MDA), total phenolic content (TPC), and chlorophyll content) of the stored samples were analyzed every 3 days in the laboratory at room temperature $\left(25 \pm 0.8{ }^{\circ} \mathrm{C}\right)$ with around 16:8 h of light: dark cycle.

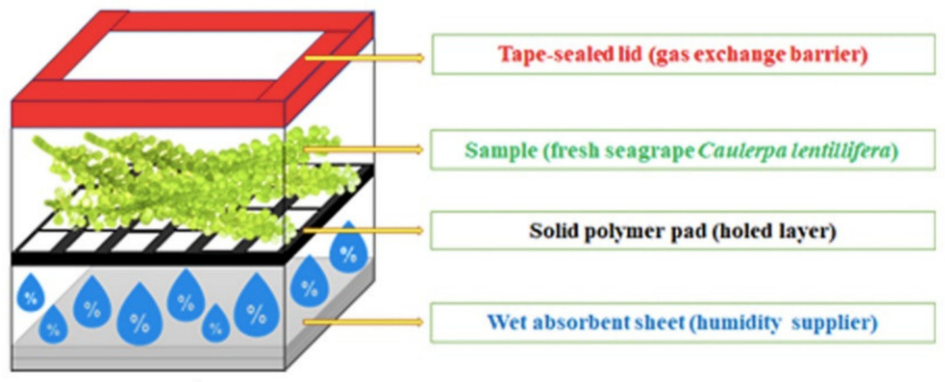

A

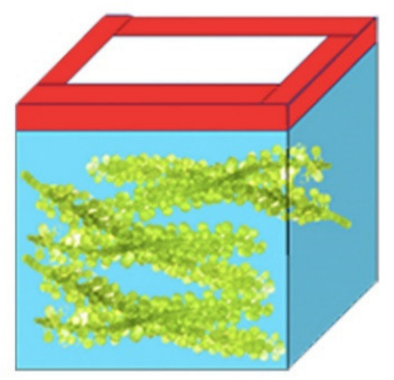

B

Figure 1. Packaging prototype for the oxidative stress environment (A) storage without seawater (B) storage within seawater.

\subsection{Alternating Current Electric Field (ACEF) Treatment for Oxidative Stress Suppression on Seagrape}

The ACEF treatment method in this study was slightly modified based on Hsieh et al. [17]. The electric field generator of the ACEF device (Model 7470, Extech Electronics Co. Ltd., New Taipei, Taiwan) provides a maximum output voltage of $20 \mathrm{kV} / \mathrm{cm}$. The ACEF device used to generate an electric current into the two-tier parallel board had a shelf spacing of $6 \mathrm{~cm}$, an output voltage of $7.5 \mathrm{kV} / \mathrm{cm}$ (a generated electric field strength of $125 \mathrm{kV} / \mathrm{m}$, and a frequency of $50 \mathrm{~Hz}$ ). The spring seagrapes' storage without seawater were placed between the two-tier board and treated for $60 \mathrm{~min}$ at $25^{\circ} \mathrm{C}$. After treating with the ACEF, the samples were stored at $25{ }^{\circ} \mathrm{C}$ for nine days and examined in triplicate to study the oxidative stress effect during post-harvest storage. The treated samples (ACEF group) 
were compared to the untreated samples (control group). The quality indicators (MDA, TPC, chlorophyll content) of the stored-samples were analyzed every three days in the laboratory at room temperature $\left(25 \pm 0.8^{\circ} \mathrm{C}\right)$ with around $16: 8 \mathrm{~h}$ of light: dark cycle.

\subsection{Water Content Assay}

According to Terada et al. [7], the water content is considered as weight loss after each storage period (M\%). The weight loss was calculated according to Equation (1) [22].

$$
\mathrm{M}(\%)=\frac{W i-W t}{W i} \times 100
$$

where $W i$ is the fresh seagrapes' initial weight after dried from surface seawater, and $W t$ is the seagrape weight after specific storage at time $t$.

\subsection{Malondialdehyde (MDA) Assay}

As an indication of oxidative stress, a without-light excess experiment was conducted with slight modifications according to Jaballi et al. [23]. Fresh seagrape branch (0.5 g) extracted by grounding within sea-sand with pestle and mortar. The extract was homogenized with $3 \mathrm{~mL}$ of $0.5 \% \mathrm{TBA}$ in $20 \%$ TCA. The homogenate boiled at $95^{\circ} \mathrm{C}$ for $30 \mathrm{~min}$. The solutions were incubated in cold water for $10 \mathrm{~min}$, then centrifuged at $10,000 \times \mathrm{g}$ for $10 \mathrm{~min}$ (Hettich Zentrifugen Mikro-120, Tuttlingen, Germany). The absorbance at 532 and $600 \mathrm{~nm}$ were recorded with an ultraviolet-visible (UV-Vis) Spectrophotometer (Chrom Tech CT8600 , Taipei, Taiwan) to calculate the malondialdehyde compound $\left(\varepsilon=155 \mathrm{mM}^{-1} \mathrm{~cm}^{-1}\right)$ based on Equations (2) and (3).

$$
\begin{gathered}
\operatorname{MDA}\left(\mu \mathrm{mol} \mathrm{g}^{-1}\right)=\mathrm{A}_{532}-\mathrm{A}_{600} / 155 \\
\mathrm{nmol} \operatorname{MDA}=\mu \mathrm{mol} \times(\mathrm{mL} \text { solution }) \times 1000)
\end{gathered}
$$

\subsection{Total Phenolic Content (TPC) Assay}

The sample extraction was adapted from García-Sánchez et al. [24]. Fresh seagrape branch $(0.25 \mathrm{~g})$ crushed in sea-sand with pestle and mortar. It was then extracted using $2.5 \mathrm{~mL}$ of $80 \%$ methanol overnight at $4{ }^{\circ} \mathrm{C}$. The solution was then centrifuged at $4500 \times g$ for $20 \mathrm{~min}$. The TPC of collected supernatant $(2 \mathrm{~mL})$ measured with Folin-Ciocalteu's method according to Nurjanah et al. [25]. Standard solution $5 \mathrm{~mL}$ distilled water and $0.5 \mathrm{~mL}$ of $50 \%$ Folin-Ciocalteu phenol reagent were added to the glass tube. After $5 \mathrm{~min}, 1 \mathrm{~mL}$ of $5 \%$ $\mathrm{Na}_{2} \mathrm{CO}_{3}$ then added and incubated in darkness for $60 \mathrm{~min}$. The solution was homogenized and measured at the absorbance of $725 \mathrm{~nm}$. The TPC of seagrape was expressed in $\mathrm{mg}$ gallic acid equivalents (GAE) per $100 \mathrm{~g}$ fresh samples. The gallic acid calibration was calculated based on Equation (4).

$$
y=0.0055 x-0.00005\left(R^{2}=0.997\right)
$$

\subsection{Chlorophyll Content Assay}

The chlorophyll content assay was slightly modified based on Guo et al. [26]. Fresh seagrape branch $(0.2 \mathrm{~g})$ was ground in sea-sand and $2 \mathrm{~mL}$ of $80 \%$ acetone with pestle and mortar until colorless. The extracted solution was then transferred to $2 \mathrm{~mL}$ centrifuge tubes and placed in the dark for $15 \mathrm{~min}$. The tubes were centrifuged for $15 \mathrm{~min}$ at $4000 \times \mathrm{g}$. Furthermore, $1 \mathrm{~mL}$ supernatant was taken into a $10 \mathrm{~mL}$ flask, and added $9 \mathrm{~mL}$ of $80 \%$ acetone. The absorbance recorded at 630, 645, 647, 663, and $664 \mathrm{~nm}$. The chlorophyll content of the fresh seagrape is calculated with Equations (5) and (6).

$$
\begin{gathered}
\text { Chlorophyll a }\left(\mathrm{mg} \mathrm{g}^{-1}\right)=11.85\left(\mathrm{~A}_{664}\right)-1.54\left(\mathrm{~A}_{647}\right)-0.08\left(\mathrm{~A}_{630}\right) \\
\text { Total chlorophyll }\left(\mathrm{mg} \mathrm{g}^{-1}\right)=8.02\left(\mathrm{~A}_{663}\right)+20.21\left(\mathrm{~A}_{645}\right)
\end{gathered}
$$




\subsection{Kinetic Analysis}

General kinetic models of zero, first and second order reactions were used to obtain the order of bioactivity reaction (in particular chlorophyll degradation) on seagrape through Equations (7)-(9), respectively.

$$
\begin{gathered}
C-C_{0}=k \times t \\
\ln \left(C / C_{0}\right)=k \times t \\
(1 / C)-\left(1 / C_{0}\right)=k \times t
\end{gathered}
$$

where $C$ is the compound content at a specific time/day, $C_{0}$ is the compound content at time/day $0, \mathrm{k}$ is the rate constant, and $\mathrm{t}$ is the storage time [27].

\subsection{Principal Component Analysis (PCA)}

The protocol of PCA was performed in the correlation (Pearson) type according to Vidal [28]. The goal of this PCA is to analyze the correlations between the variables and to find out if the changes in physicochemical quality of seagrape are very different from the quality in different sample conditions during post-harvest storage. The means $(n=3)$ of total chlorophyll content, TPC, MDA compound, and water loss on seagrape were indicated as the variables. Those variables were then analyzed by using XLSTAT software (Microsoft, Washington, USA) in response to the storage treatment differences that indicated as the observation labels. The correlation output was set up in a level of test significance at $5 \%$.

\subsection{Statistical Analysis}

All of the data derived from each indicator were expressed as means, and standard deviations were expressed as the error bars. Statistical data-processing was analyzed with SPSS 22 software (SPSS Institute, New York, USA). Statistical analysis was performed with one-way analysis of variance (ANOVA) Tukey's multiple range tests, and statistical significance was defined at $p<0.05$ [26]. Each analysis in this study was performed in triplicate.

\section{Results and Discussion}

\subsection{Effect of Oxidative Stress on Water Content of Seagrape}

Almost the entire algae tissues consisted of water by showing more than $85 \%$ of moisture according to many works of literature. Under water-limited conditions, the algae cannot regulate their water content that leads to oxidative stress [29]. Corresponding to the result in Figure 2, the weight loss of the seagrape without seawater during storage in every season is increasing as the representative of water loss [7,30]. While the without-seawater storage loses water content, the within-seawater storage increases their weight up to $10 \%$ after nine days of storage (Figure 2). This phenomenon occurred due to the growth rate of the harvested seagrape keeps continuing if it is stored in seawater.

However, the improper storage due to water-limited condition may be considered as an oxidative stress condition by showing a lack of specific growth rates $\left(<1 \% \mathrm{~d}^{-1}\right)$. Guo et al. $[26,31]$ reported the specific growth rate of seagrape $C$. lentillifera in China is around $1 \%$ to $7 \% \mathrm{~d}^{-1}$ in temperatures of 20 to $30{ }^{\circ} \mathrm{C}$ and salinities of 30 to 40 . Shiroma in Terada et al. [7] also mentioned the growth of seagrape in winter takes a longer time than in summer. Figure 2 also shows the winter seagrape on the within-seawater storage experiencing greater weight loss than the spring and summer. This phenomenon might be due to several branches had been experienced several cellular damages (limped and yellowish thalli) that are influenced by their environment and cultivation process, then it becomes more severe during post-harvest storage. 


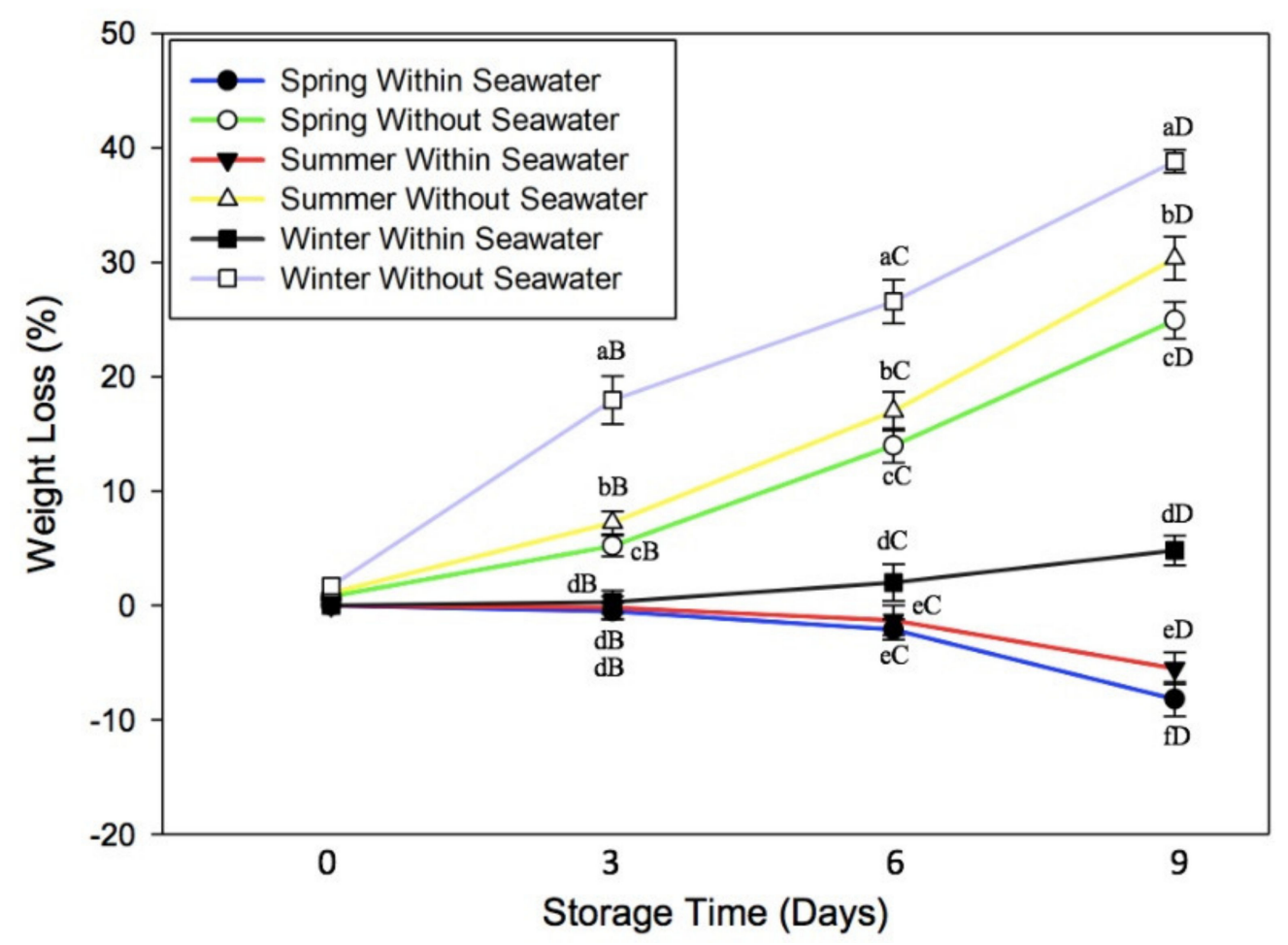

Figure 2. Oxidative stress effect on water content of seagrape in different seasons during post-harvest storage. The data express means $(n=3)$ with the error bar shows standard deviation. ${ }^{\mathrm{a}-\mathrm{f}}$ Means express the significant differences in the same storage time $(p<0.05)$. B-D Means express the significant differences in the same treatment $(p<0.05)$.

Terada et al. [7] described the water content that remained at around $75 \%$ within a week of storage without seawater indicating the seagrape is still fresh by maintaining its photosynthesis performance (an ability of desiccated seagrape to increase the maximum quantum yields after re-immersion in seawater). However, in this study, the water content around $75 \%$ (Figure 2) indicates that the seagrapes' quality might not be considered fresh due to the occurrence of high discoloration on winter seagrape on day 6. In contrast, the quality freshness of seagrape in summer and spring for the without-seawater storage might be guaranteed up to one week by showing the water content still remained over $85 \%$ and their discoloration occurred after over one week of storage. Previous studies mentioned the water content inside a sample tends to affect its discoloration that is influenced by the storage environment such as temperature, $\mathrm{pH}$, etc. [32-35]. The weight loss in this study represents the physical quality of the stored-seagrape to show the membrane fluidity state, where it became limp as well as the oxidative stress period lengthening $[21,36]$. Although seagrape has high desiccation-tolerance, prolonged oxidative stress diminishes algae rehydrate ability that damages the cell structure, and increases the water loss during post-harvest storage $[7,37]$. However, this study reveals that the lower the water content the faster the discoloration occurred on seagrape. Furthermore, this study also indicates the water content (thalli weight) of the seagrape represents the physical state of the seagrape, which increases the thalli weight by growing new stalks during storage within seawater.

\subsection{Effect of Oxidative Stress on Malondialdehyde Compound of Seagrape}

Based on Figure 3A, the seagrapes' generated MDA compound during post-harvest storage is increasing significantly for the without-seawater storage. Saito et al. [38] reported that seagrape contains a high level of polyunsaturated fatty acid (PUFA) and multiple essential amino acids and lipids $[39,40]$. Oxidative stress induces the biochemical compounds of algae that are prone to be lost indirectly with cell viability loss [41]. Oxidative stress leads to the damage of PUFA that causes lipid peroxidation, which is an oxidative 
free radical that generates MDA compound on seagrapes' membrane phospholipids [36]. Wang et al. [42] also reported that the multiple cellular changes caused the repair capacity loss and higher membrane permeability of the seagrape under oxidative stress (osmotic pressure). Lipid peroxidation from oxidative stress on algae started by the abiotic stresses that trigger the imbalanced reactive oxygen species (ROS) production in the metabolism cell of algae, resulting in the chain breakage and the induction of membrane fluidity and permeability [43].
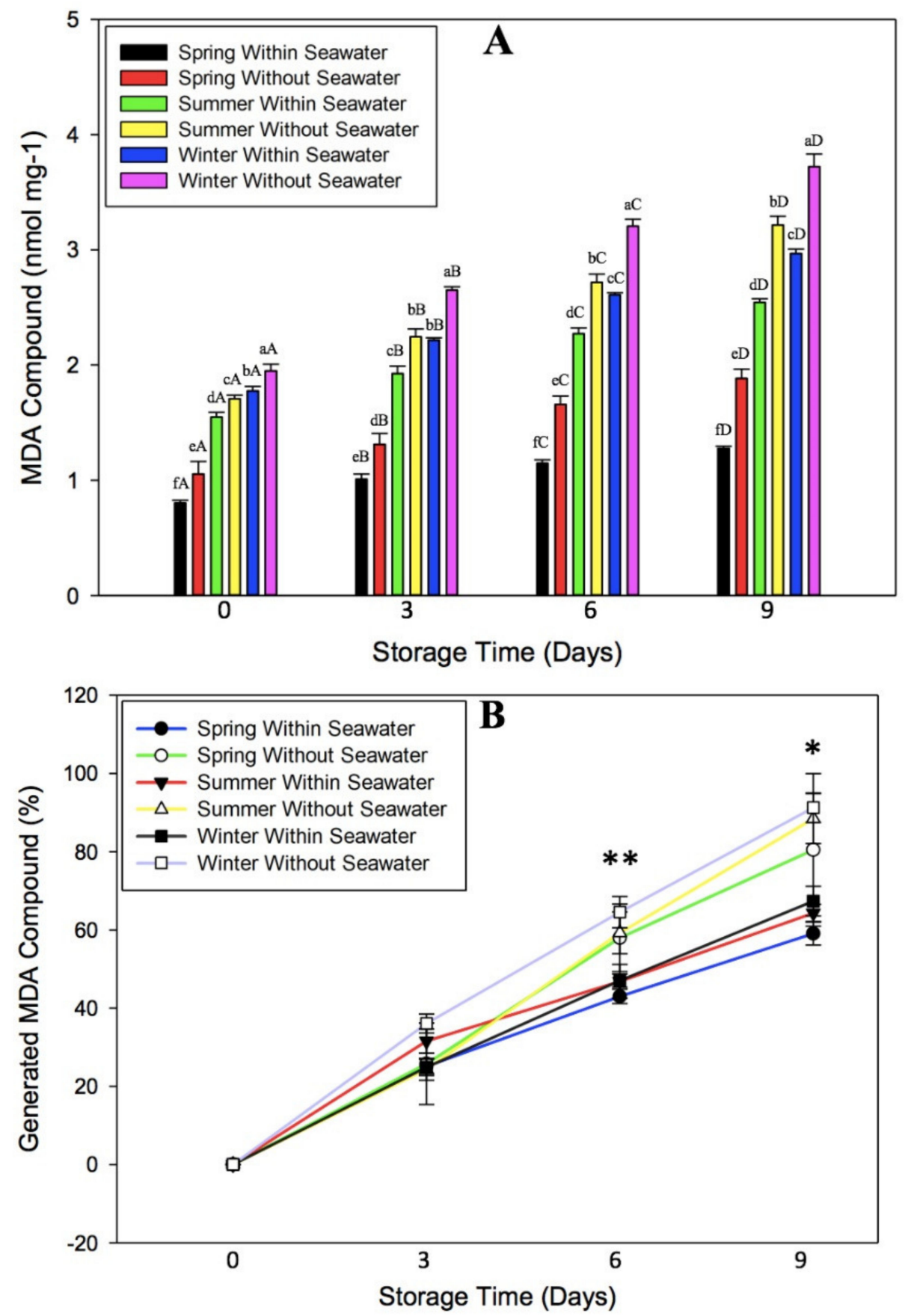

Figure 3. Oxidative stress effect on malondialdehyde (MDA) compound of seagrape in different seasons during post-harvest storage (A) MDA compound (B) generated MDA compound rates. The data express means $(n=3)$ with the error bar shows standard deviation. ${ }^{\text {a-f }}$ Means express the significant differences in the same storage time $(p<0.05)$. ${ }^{A-D}$ Means express the significant differences in the same treatment $(p<0.05)$. The star marks express the significant differences as respectively* $(p<0.05)$, and ${ }^{* *}(p<0.01)$. 
The membrane quality loss of seagrape in this study is imaged by Figure 3B, the storage without seawater and within seawater generating MDA up to $80 \%$ and $60 \%$, respectively. The case of an increased MDA on the within-seawater storage might be caused by the harvesting treatment that damages the seagrapes' tissue and cell wall. Also, this phenomenon may happen because the within-seawater storage might not be the proper environment, but it keeps the MDA in a lower compound than the withoutseawater storage. Gaschler and Stockwell [44] described how lipid peroxidation has the main role in altering the membrane cell integrity, which is that the higher the generatedproducts the greater the generated-damages. Kong et al. [45] mentioned MDA is an essential physiological status indicator during plant growth, which is generated by lipid peroxidation under stress conditions. In this study, the seagrape may experience the stress condition by showing less than $10 \%$ of specific growth rates after nine days of storage within seawater. This phenomenon may be caused by the excess provided nutrients are not optimal, the stem will grow new stalks and make the algae weaken by sharing nutrients to grow new stems in the limited-seawater case.

\subsection{Effect of Oxidative Stress on TPC of Seagrape}

The TPC result in this study shows similarity to the TPC content of seagrape found in the other sub-tropical countries, where it contains TPC of less than $10 \mathrm{mg} \mathrm{GAE} \mathrm{g}^{-1}$ in fresh weight (Figure 4). However, the TPC of stored-seagrape is decreasing as well as the oxidative stress time lengthens (Figure 4A). Kim et al. [46] also reported the TPC of kiwifruit Actinidia arguta decreased during post-harvest handling and storage. Studies indicated that the phenolic compound was broken down into intermediate metabolites in algae, thus implying that the phenol had been degraded through a biodegradation process [47]. Furthermore, phenolic compounds are easily converted to ROS due to photoinhibition in aquatic organisms, resulting in the activation of antioxidant defenses $[47,48]$. In this study, the degradation of TPC caused by oxidative stress occurred under both post-harvest storages, and the degradation may trigger further enzymatic reactions that lead to possible cell damage. TPC of spring seagrape shows higher content than in the summer and winter, resulting in lower degradation rates due to oxidative stress condition (Figure 4B). This may indicate the higher the biomass compositions the slower the decomposition rates will occur on seagrape during oxidative stress.

Post-harvest handling and the environment have the main roles in influencing the nutritional compositions of seagrape [49]. Nurjanah et al. [25] mentioned the chemical compositions including TPC are also influenced by sunlight, habitat, harvesting time, herbivore presence, and plant health conditions. As evidence; Caulerpa spp. in tropical countries contains TPC of more than $15 \mathrm{mg} \mathrm{GAE} \mathrm{g}^{-1}$ and in subtropical countries contains TPC less than $15 \mathrm{mg} \mathrm{GAE} \mathrm{g}^{-1}$ [25,41,50-52]. Furthermore, Mekinić et al. [53] also reported the TPC of brown seaweed varies in different locations and countries. On the other hand, several studies reported that the TPC is also influenced by the kind of solvents during extraction process. Monteiro et al. [54] reported a vary of TPC on green alga Ulva rigida derived from different extraction solvents. 

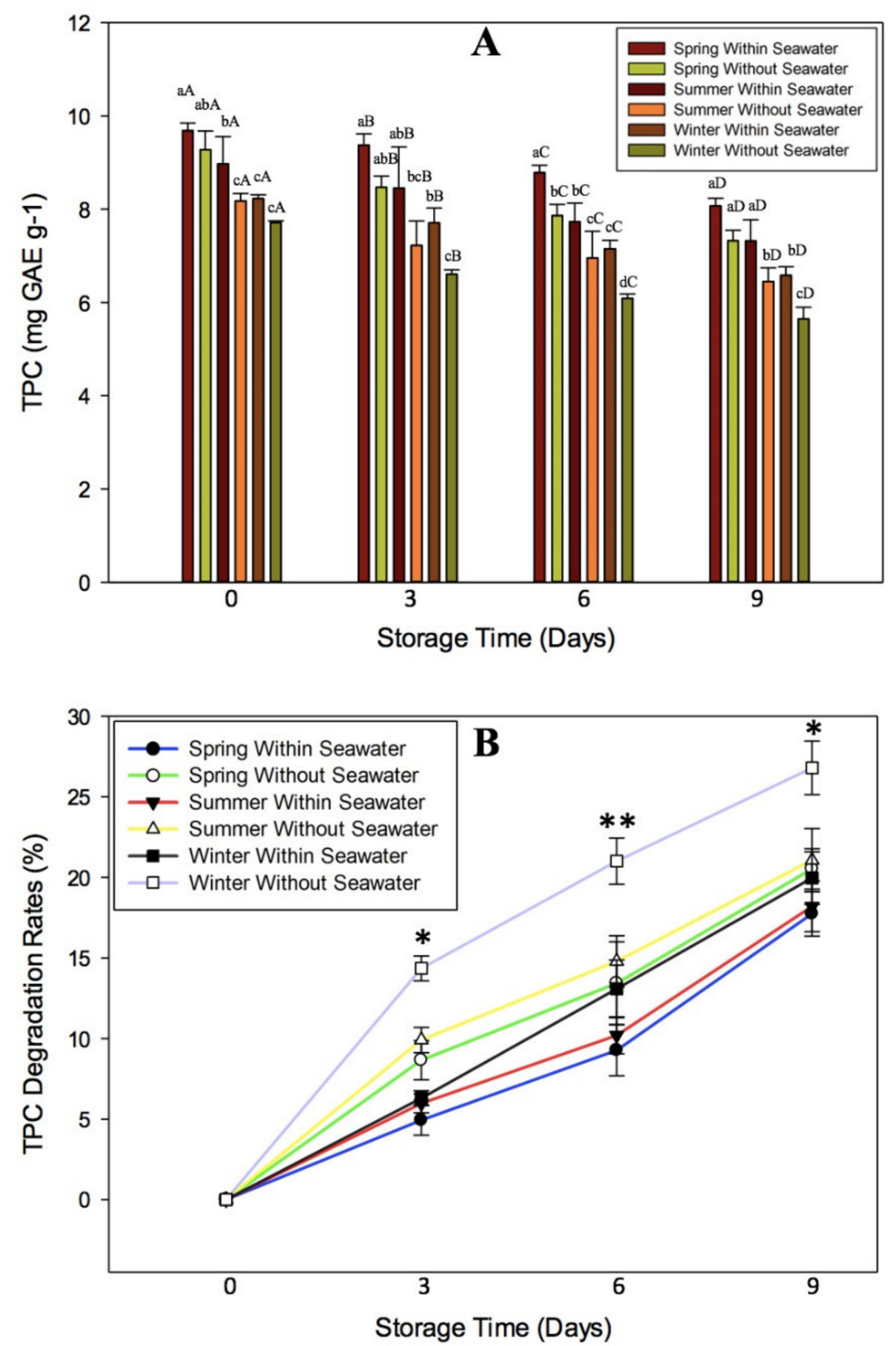

Figure 4. Oxidative stress effect on total phenolic content of seagrape in different seasons during postharvest storage (A) total phenolic content (TPC) (B) TPC degradation rates. The data express means $(n=3)$ with the error bar shows standard deviation. ${ }^{\text {a-d }}$ Means express the significant differences in the same storage time $(p<0.05)$. A-D Means express the significant differences in the same treatment $(p<0.05)$. The star marks express the significant differences as respectively $*(p<0.05)$, and ${ }^{* *}(p<0.01)$.

\subsection{Effect of Oxidative Stress on Chlorophyll Content of Seagrape}

Chlorophyll is the abundance of pigment (chemical compound) found in green algae. This pigment is the main compound that influences the physical color and photosynthesis ability of seagrape. According to Figure 5, we found that the chlorophyll a and the total chlorophyll content is higher in spring that followed by summer and winter, respectively. Paul et al. [55] reported seagrape C. lentillifera from Kissing Point (Townsville, Australia) 
contains $2.58 \mathrm{mg} \mathrm{g}^{-1}$ of chlorophyll a and $4.10 \mathrm{mg} \mathrm{g}^{-1}$ of total chlorophyll content, which is shown with close similarities with the spring seagrape (Figure $5 \mathrm{~A}, \mathrm{C}$ ). This phenomenon might be caused by the submerged light intensity in spring being lower than in summer and winter. Guo et al. [26] also reported the lower irradiance resulting in higher chlorophyll content of the cultivated seagrape $C$. lentillifera.
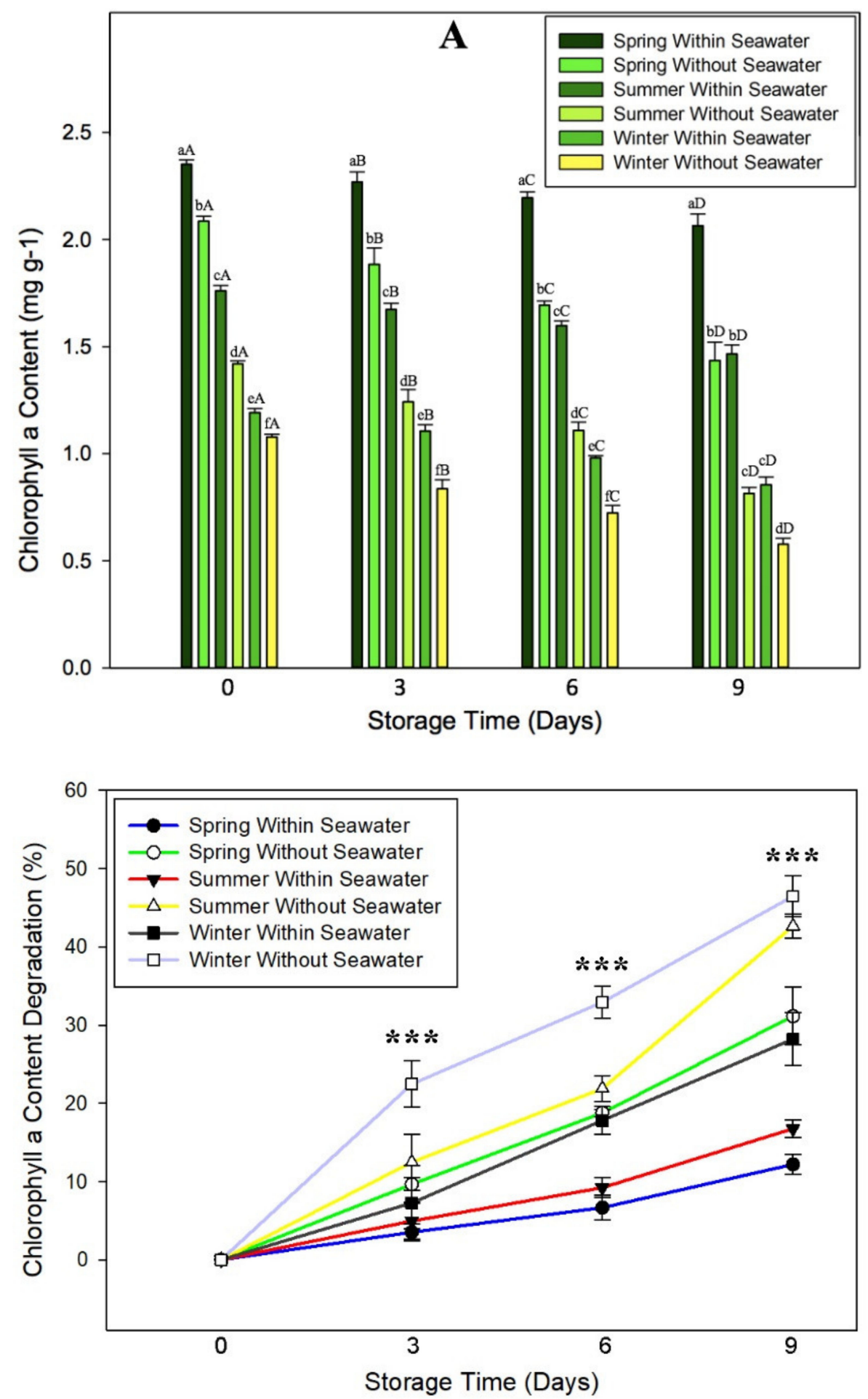

Figure 5. Cont. 

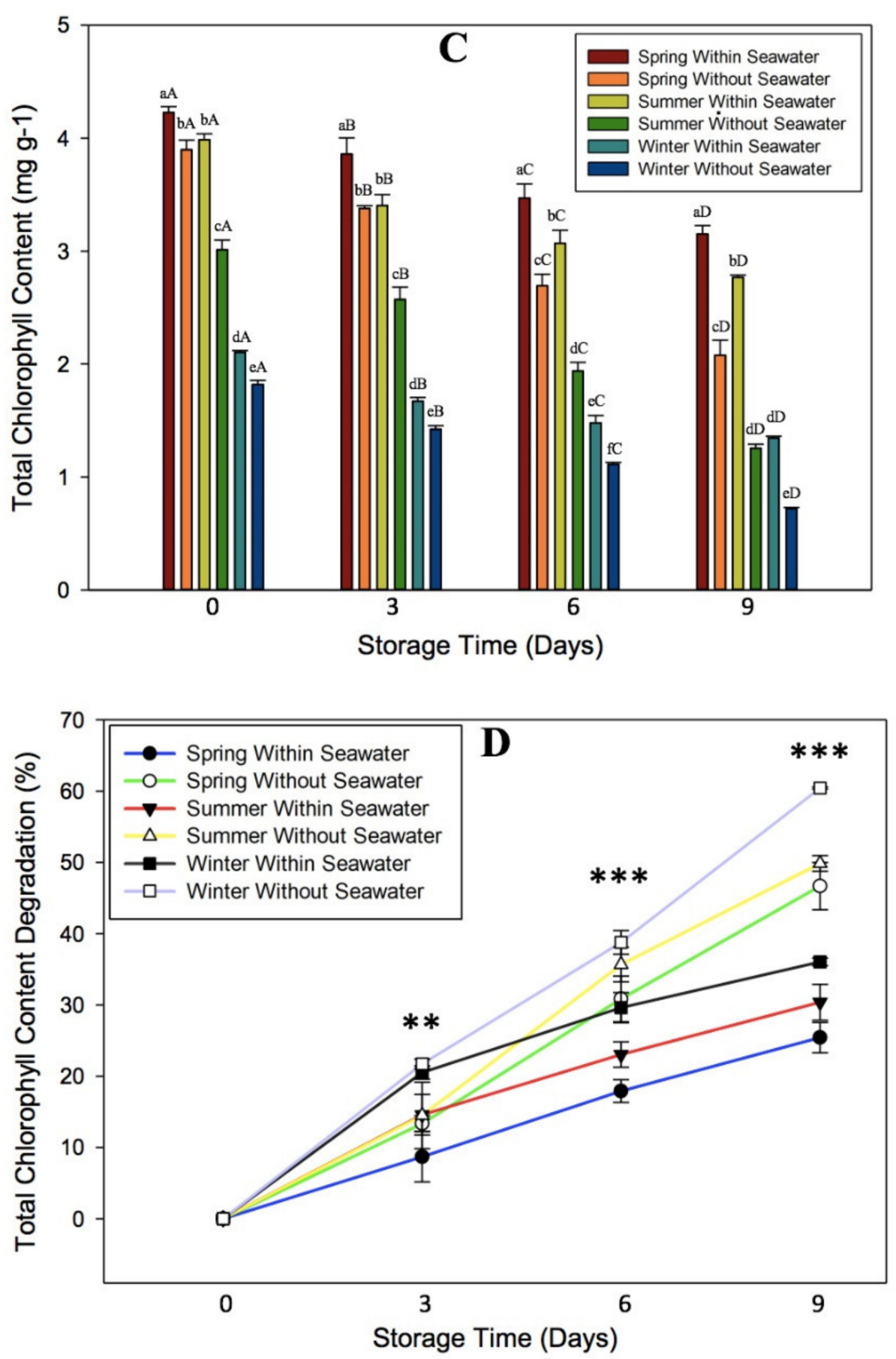

Figure 5. Oxidative stress effect on chlorophyll content of seagrape in different seasons during postharvest storage (A) chlorophyll a content $(\mathbf{B})$ chlorophyll a degradation rates $(\mathbf{C})$ total chlorophyll content (D) total chlorophyll content degradation rates. The data express means $(n=3)$ with the error bar shows standard deviation. ${ }^{\mathrm{a}-\mathrm{f}}$ Means express the significant differences in the same storage time $(p<0.05)$. A-D Means express the significant differences in the same treatment $(p<0.05)$. The star marks express the significant differences as respectively ${ }^{* *}(p<0.01)$, and ${ }^{* * *}(p<0.001)$.

The degradation of chlorophyll content due to stressed condition indicates the occurrence of photoprotection mechanism over reducing light absorbance by reducing the content of chlorophyll [56]. However, some studies have reported many enzymes caused chlorophyll degradation in several key mechanisms that covered by Pongsri et al. [57], in particular; chlorophyllase (CHLASE), chlorophyll-degrading peroxidase (CHL-POX), pheophytinase (PPH), and Mg-dechelatase (MD). By oxidative stress effects during storage, 
the chlorophyll content of seagrape in a particular storage for a long time is oxidized by CHLASE that remove phytol chain to yield chlorophyllide (bright green thalli). Acids that occupy $\mathrm{Mg}^{2+}$ ion in pheophytin cleaved by MD and $\mathrm{PPH}$ then replaced by $\mathrm{H}^{+}$ions to produce pheophytin, resulting in swamp-green thalli (initial color loss). CHL-POX also oxidizes chlorophyll to produce C13-hydroxychlorophyll (colorless) in the presence of ROS and phenolic compounds.

Based on Figure 5B,D, the chlorophyll a and total chlorophyll content of the seagrape in the storage without seawater is decreasing as the oxidative stress period lengthens by reaching $45 \%$ and $60 \%$ of degradation rates, respectively. The seagrape in the storage within seawater is also exceeding $20 \%$ and $30 \%$ of total chlorophyll degradation rates. As the result, the chlorophyll degradation is marked with the changes of the initial color of seagrape during the storage time lengthens. Therefore, we conclude that oxidative stress leads to chlorophyll degradation during post-harvest storage. This result is corresponding to Aiamla-or et al. [58] and Luo et al. [59] who reported the stored-broccoli had experienced high chlorophyll degradation with significant color changes during storage. In this case, we can indicate the pigment concentration in plants is mostly affected by solar irradiation (light irradiance), environment conditions (ocean current and nutrient), and post-harvest handling and storage.

\subsection{Effect of Cultivation Season on Physicochemical Quality of Seagrape under Post-Harvest Storage}

Previous studies have reported that spring and summer are the best time to cultivate algae or seaweed due to its higher biomass and specific growth rates [60,61]. In this study, we found the physicochemical quality of seagrape are significantly different in different seasons. The chlorophyll content and TPC of seagrape in spring has higher physicochemical quality than in summer and winter. The results from this research corresponding to the seasonal effect on the chemical content compositions, physiology, and growth of algae or seaweed [30,62]. Furthermore, Moreira et al. [63] and Gosch et al. [64] reported PUFA on algae was higher in winter than summer and spring, which results in higher lipids to generate MDA [65]. This phenomenon due to the lower threshold of the temperature of survival of this seagrape changes from warm temperature in summer to the cold temperature in winter. The degree of unsaturation of the fatty acids of membranes increases to maintain the membranes in their functional liquid-crystalline state not to form a solid gel-state. Choo et al. [66] also reported that MDA in winter is generated with higher compounds when grown in seawater medium.

This study has characterized directly the thalli physical state of seagrape in these three different seasons by observing the obvious discoloration (pheophytin, chlorophyllide, and pheophorbide yield) on the seagrapes' appearance. The establishment of an oxidative stress effect on membranes composition changes their physical states as the thalli color become darker. As a result, the spring seagrape has a longer time to experience discoloration than the summer seagrape, and the winter seagrape experienced faster discoloration along with faster spoilage. Discoloration focused on in this study is due to the storage environment especially oxygen and irradiance that may catalyze chlorophyll oxidation reactions to cause the thalli color to become dark green, swamp green, brown-green, bright green, and colorless $[57,67,68]$. Therefore, this study has proven that oxidative stress will reduce the physicochemical quality of seagrape during post-harvest storage.

The consequence of aerobic metabolism is inevitably accumulating ROS on seagrape to act in signaling events such as a response to photosynthesis, growth, and adaptation to the stressed environment [69-71]. The toxicity of ROS will lead to the physicochemical deterioration in seagrape due to the oxidative stress during post-harvest storage. Nofiani et al. [72] explained the hemolytic activity observation was used to monitor the lysis of seagrape. Hemolytic activity might interfere with the membrane cells and induce hemolytic anemia as the presence of astringent phenolic content on seagrape. Furthermore, Jespersen et al. [73] explained the chlorophyll degradation caused by the presence of $\mathrm{H}_{2} \mathrm{O}_{2}$ and some phenolic compounds. In this study, desiccation caused by oxidative stress may 
play the role in changing some of the phenolic compounds to become astringent as well as producing ROS to generate MDA, resulting in the chlorophyll degradation.

3.6. Effect of Oxidative Stress on Kinetics of Storage Time to the Chlorophyll Content of Seagrape in Different Cultivated Seasons

Previous studies reported different samples will display different kinetic reactions of chlorophyll degradation during storage [68,74]. Nonetheless, Sonar et al. [75] reported corresponding results to this study, which is the possibility to apply multi-order reactions. Based on the kinetics table for of the storage within seawater and without seawater in different cultivated seasons (Table 1), the all-order reactions are revealed as the mechanisms of enzymatic-chlorophyll degradation. The result in spring indicates second-order reaction as the kinetics of chlorophyll degradation for the storage within seawater and without seawater, where both reactions show the highest coefficient of determination $\left(R^{2}=0.9999\right.$ and 0.9991, respectively). Furthermore, the result in summer indicates the first-order reaction as the kinetics of chlorophyll degradation for both the storage within seawater and without seawater with $\mathrm{R}^{2}=0.9999$ and 0.9986 , respectively. In winter, the result indicates the zero-order reaction as the kinetics of chlorophyll degradation for the storage within seawater and without seawater by showing the highest $R^{2}$ ( 0.9928 and 0.9393 , respectively) than other reactions.

Table 1. The $k$ and $R^{2}$ value for kinetics of total chlorophyll degradation on seagrape in different seasons during nine days of post-harvest storage.

\begin{tabular}{cccccccc}
\hline \multirow{2}{*}{$\begin{array}{c}\text { Cultivation } \\
\text { Season }\end{array}$} & $\begin{array}{c}\text { Post-Harvest } \\
\text { Storage }\end{array}$ & \multicolumn{2}{c}{$\begin{array}{c}\text { Zero-Order } \\
\text { Reaction }\end{array}$} & \multicolumn{2}{c}{$\begin{array}{c}\text { First-Order } \\
\text { Reaction }\end{array}$} & \multicolumn{2}{c}{$\begin{array}{c}\text { Second-Order } \\
\text { Reaction }\end{array}$} \\
\cline { 3 - 8 } & Within SW & -0.1228 & 0.9968 & -0.0283 & 0.749 & 0.0084 & 0.9999 \\
\hline \multirow{2}{*}{ Spring } & Without SW & -0.1923 & 0.9982 & -0.0598 & 0.9984 & 0.0191 & 0.9991 \\
& Within SW & -0.1606 & 0.9986 & -0.0455 & 0.9999 & 0.013 & 0.9995 \\
\multirow{2}{*}{ Summer } & Without SW & -0.1642 & 0.9871 & -0.0703 & 0.9986 & 0.0287 & 0.9986 \\
\hline \multirow{2}{*}{ Winter } & Within SW & -0.0371 & 0.9928 & -0.0349 & 0.9891 & 0.033 & 0.9846 \\
& Without SW & -0.041 & 0.9393 & -0.0729 & 0.8417 & 0.0757 & 0.874 \\
\hline
\end{tabular}

The selected order reaction is indicated by the highest $R^{2}$. Abbreviation: $\mathrm{SW}=$ Seawater.

In this study, different seasons follow different kinetic reactions of chlorophyll degradation with different speed-rates. This phenomenon might be caused by the physicochemical properties in each season. In winter, the lower physicochemical quality of seagrape acts as the catalyst to experience early discoloration and faster chlorophyll degradation follow zero-order reaction. The higher physicochemical quality in summer and spring follow firstorder and second-order reactions, in which the occurrence of decomposition is slower to experience chlorophyll degradation and discoloration. Several studies have reported zeroorder reaction as the kinetic for chlorophyll degradation and color change [76,77], which may be related to the early discoloration on winter seagrape. Nonetheless, the first-order reaction describes the chlorophyll degradation caused by enzyme activity $[78,79]$, which may result in the higher pheophorbide yield as the oxidative stress condition lengthens. Alike the first-order reaction, the second-order reaction is also indicated as the appropriate kinetic order to explain the chlorophyll degradation due to enzyme activity over time according to Benlloch-Tinoco et al. [80].

\subsection{Effect of ACEF on Physicochemical Quality of Seagrape during Post-Harvest Storage}

According to the observation on the physicochemical quality of seagrape cultivated in different seasons, the spring seagrape was found to be the best cultivar that has the greatest physicochemical quality during storage than other seasons. Therefore, the ACEF technology has been applied to the spring seagrape in this study. Since the oxidative stress condition leads to the imbalance ROS accumulation, it enhanced the MDA production that is causing chlorophyll degradation to reduce the TPC and water content on seagrape during 
post-harvest storage. In this study, the application of EF technology aims to suppress the ROS production according to Zhao et al. [81]. Furthermore, the ACEF treatment is seemed to have a significant effect in maintaining the physicochemical quality of seagrape during post-harvest storage that can be seen in Figure 6.

\subsubsection{Effect of ACEF on Water Content of Seagrape}

The oxidative stress effect will remove the unbound water due to the seagrape tissues consisting of more than $90 \%$ of water [1,2]. Because of the expanding steam above the surface of the seagrape, it results in vapor pressure differentials being created that are strong enough to break the cellular structure [22]. This study indicates the phenomenon might cause high cell wall permeability on seagrape to experience water loss. The water loss of seagrapes in this study was continuously increased during storage. This result is corresponding with the previous studies that covered by Contreras-Porcia et al. [82], which reported the occurrence of significant water loss on algae due to oxidative stress condition. However, this study reveals the effect of ACEF in lowering water loss by reaching a 10\% reduction after nine days of storage (Figure 6A).

The result in this study corresponds with Cao and Gao [83], they reported that EF is a preservation method of physical modification. Furthermore, the ACEF preservation technology in this study may show better performance in reducing the weight loss of seagrape after nine days of storage. Respectively, the application of 4-methoxy cinnamic acid and on a mushroom and E-beam irradiation at a dose of $1 \mathrm{kGy}$ on lime only reduces less than $5 \%$ of weight loss after 9 days of storage $[57,84]$. Nevertheless, the effectiveness might be affected by the initial condition and the characteristic of the fresh treated sample after harvested.

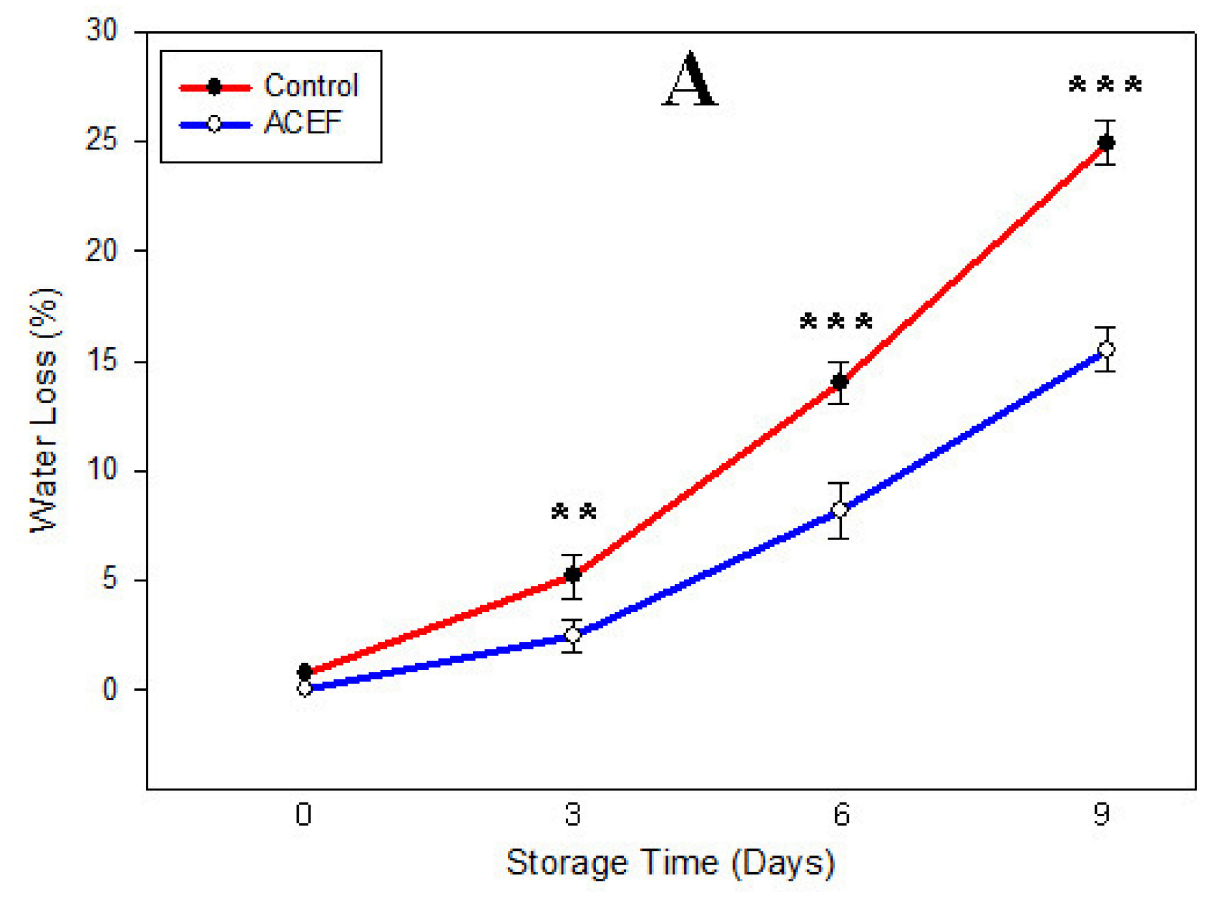

Figure 6. Cont. 

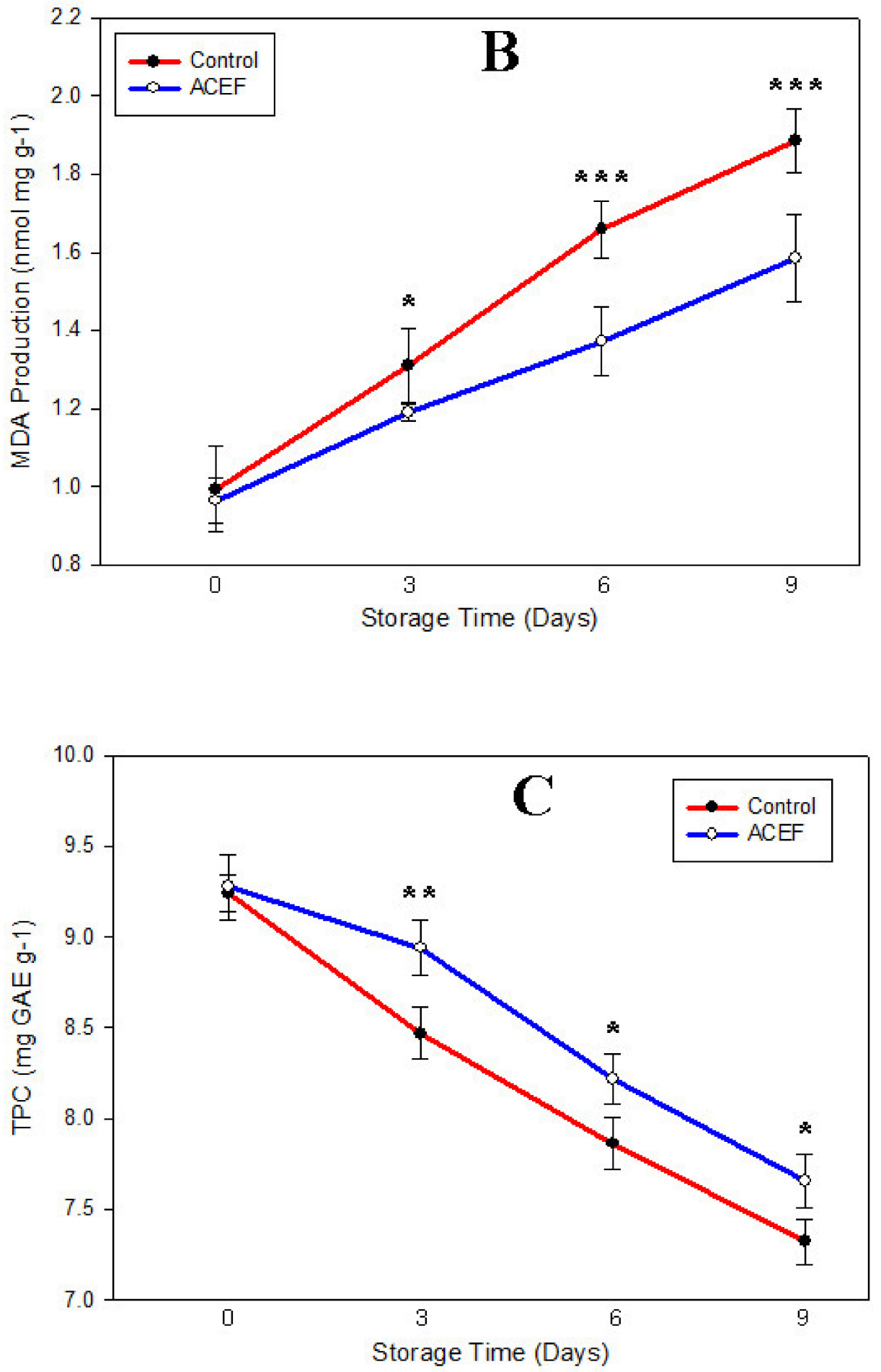

Figure 6. Cont. 

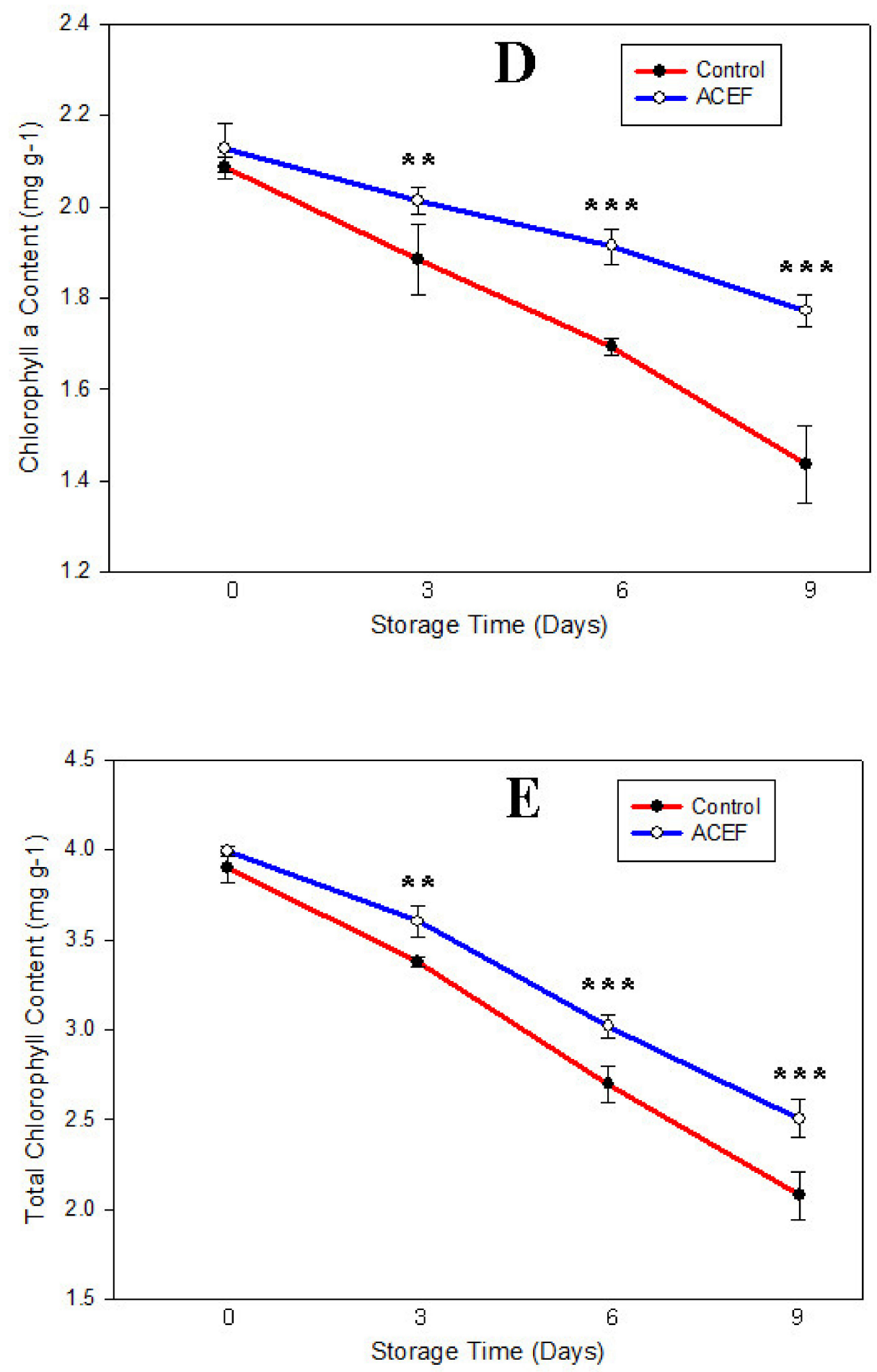

Figure 6. Effect of alternating current electric field (ACEF) on physicochemical quality of seagrape in spring during post-harvest storage (A) water loss (B) MDA (C) TPC (D) chlorophyll a content (E) total chlorophyll content. The data express means $(n=3)$ with the error bar shows standard deviation. The star marks express the significant differences as respectively ${ }^{*}(p<0.1),{ }^{* *}(p<0.05)$, and ${ }^{* * *}(p<0.01)$.

\subsubsection{Effect of ACEF on MDA of Seagrape}

Seagrape packaging may also be determined as an oxidative stress condition, which is the algae stored in a dehydrated condition environment [7,29]. Since seagrape contain high polyunsaturated fatty acids (PUFA), oxidative stress leads to the damage of PUFA that causing lipid peroxidation on seagrapes' membrane phospholipids [36,38]. Free radicals 
are detected in MDA, a product of lipid peroxidation and damaged cell membrane integrity index resulting from oxidative stress and enzymatic activities [85-87]. Tavakoli et al. [88] and Abedi et al. [89] have investigated the effectiveness of electric fields effect in interfering with the chlorophyll pigments, which found to be effectively reduced the free fatty acid (PUFA) and peroxidase value (ROS) of refined sunflower oil.

As with water content reduction, this study also reduces the generated MDA compound on the ACEF group during nine days of storage (Figure 6B). Bensalem et al. [90] found a significant effect of EF on the permeability and structure change of membrane cell wall in microalgae Chlamydomonas reinhardtii. Hu et al. [84] reported the similarity to the result in this study, in which the water content of seagrape is reduced and the generated MDA in seagrape is increased with the lengthening of storage time. Nonetheless, the ACEF treatment inhibited the production of MDA on seagrape that is corresponding with the result proposed by Yan et al. [91]. This study showed a significant effect in reducing the MDA production of seagrape during nine days of storage. This study found the ACEF treatment might maintain the seagrapes' water content level by lowering the MDA product during post-harvest storage.

\subsubsection{Effect of ACEF on TPC of Seagrape}

Regarding the presence of phenolic content, it is also affecting the post-harvest quality status of seagrape that will change due to enzymatic activity during post-harvest treatment $[3,92]$. Based on Figure 6C, the TPC of seagrape was decreasing continuously from day 0 to day 9 . The phenomenon may be caused by the non-enzymatic detoxification system of seagrape to resist the ROS during storage [93]. Jiang et al. [94] stated that the presence of phenolic compounds helps contribute to the sensorial attributes (taste, color, texture, and aroma). This study found the obvious degradation of seagrapes' color and texture (Figure 7). However, ACEF treatment reveals a promising result by reducing the TPC degradation of seagrape under oxidative stress packaging.

Hsieh et al. [17] explained the correlation between the TPC and membrane cell integrity, in which inhibiting the enzymatic activity will suppress the degradation of TPC as well as the membrane cell integrity. Petriccione et al. [95] found post-harvest treatment with chitosan that produced less MDA and mass loss $(<5 \%$ inhibition after 10 days of storage), resulting in fewer phenolic compounds on grapes. This study reveals that the more compact the membrane tissues the lower the degradation occurred on seagrape. Zhao et al. [81] claimed that plant injury is related to an elevated antioxidant system to resist ROS accumulation. This indicates that TPC in seagrape can be maintained with ACEF treatment through enzymatic activity inhibition that leads to a shelf-life extension.
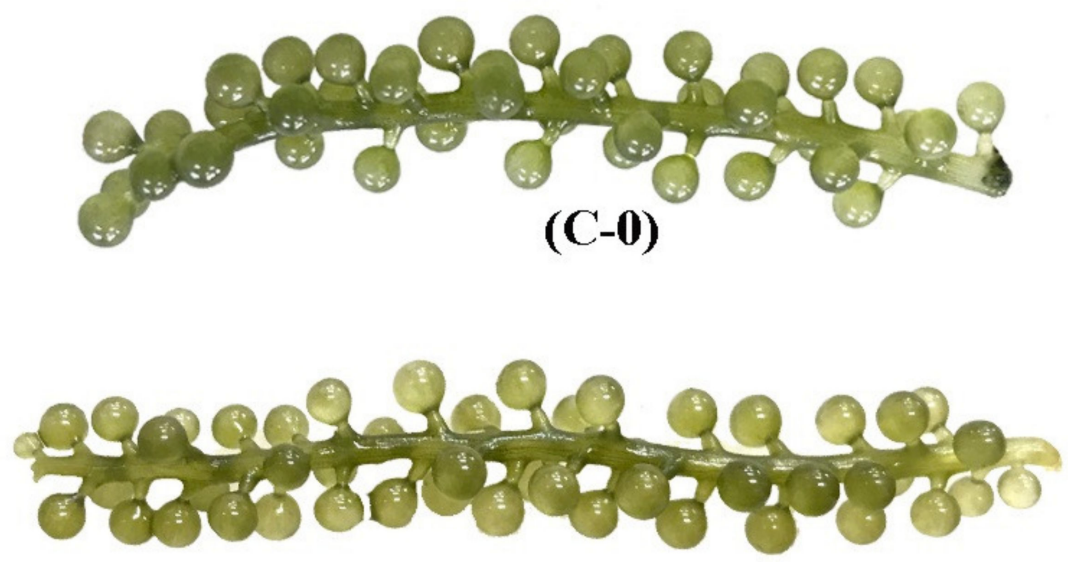

(A-0)

Figure 7. Cont. 

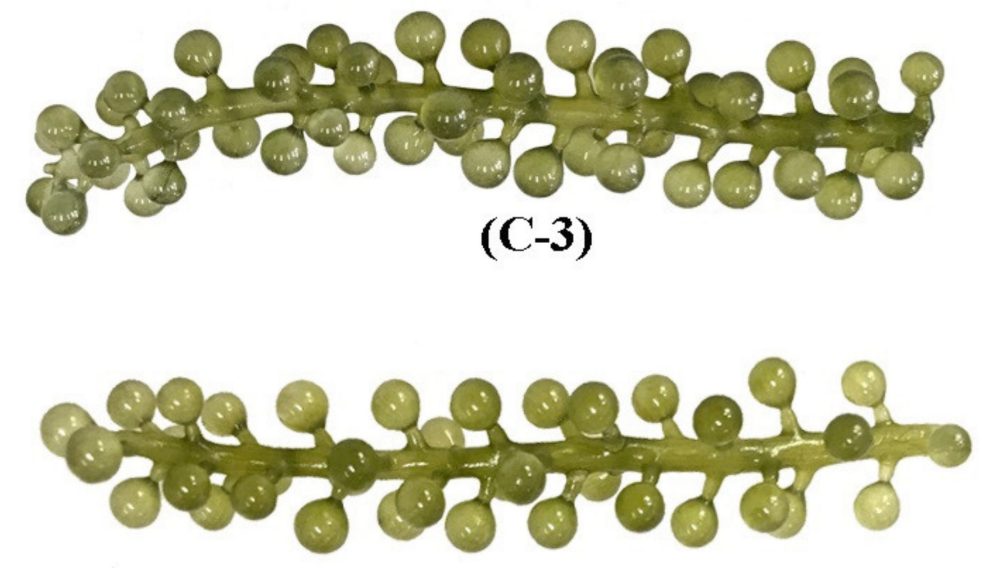

(A-3)

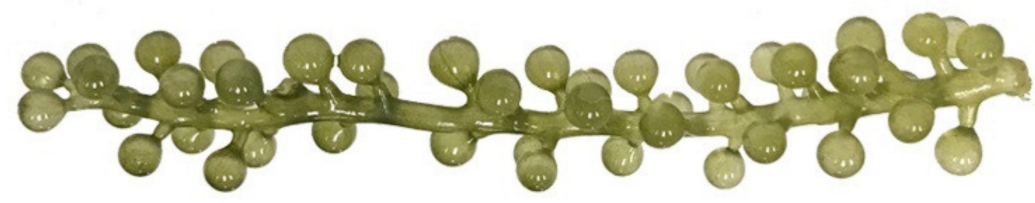

(C-6)
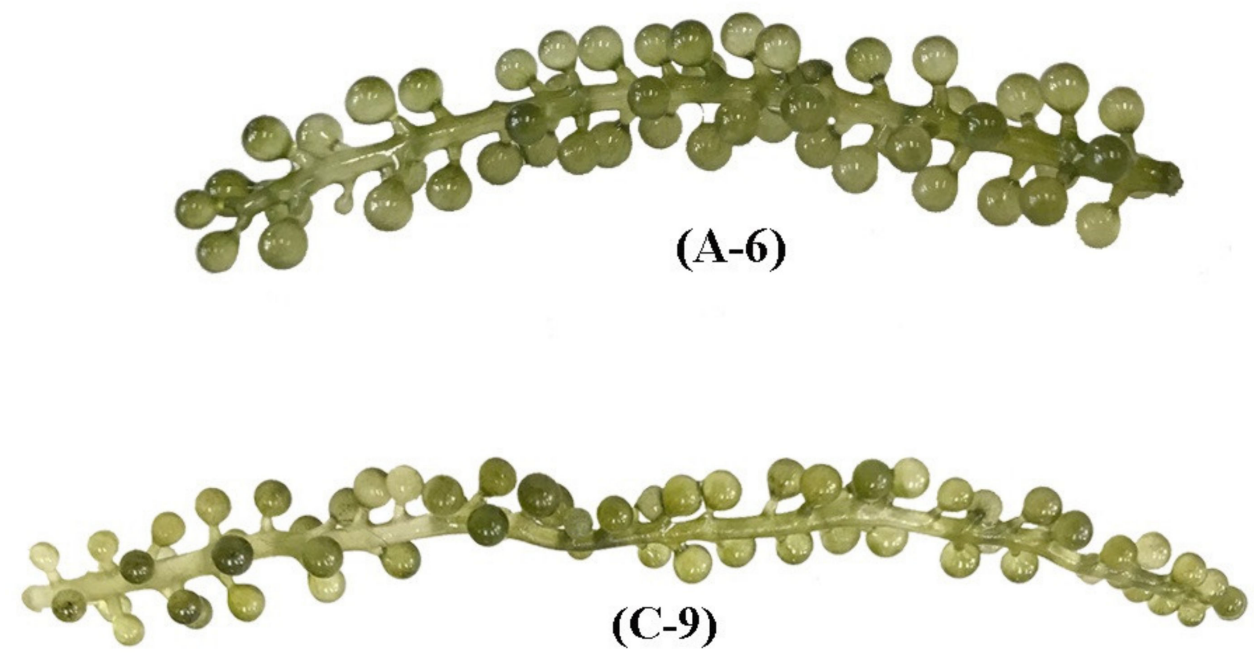

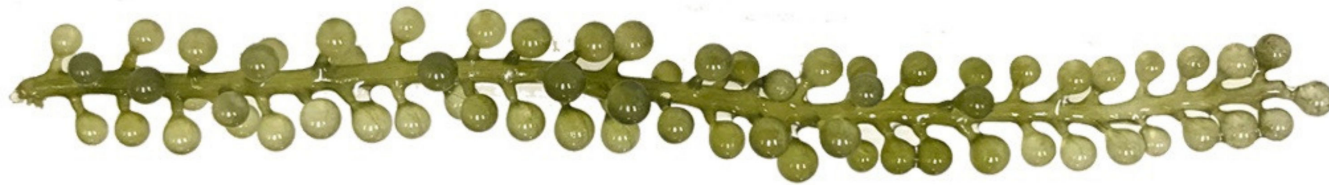
(A-9)

Figure 7. Cont. 

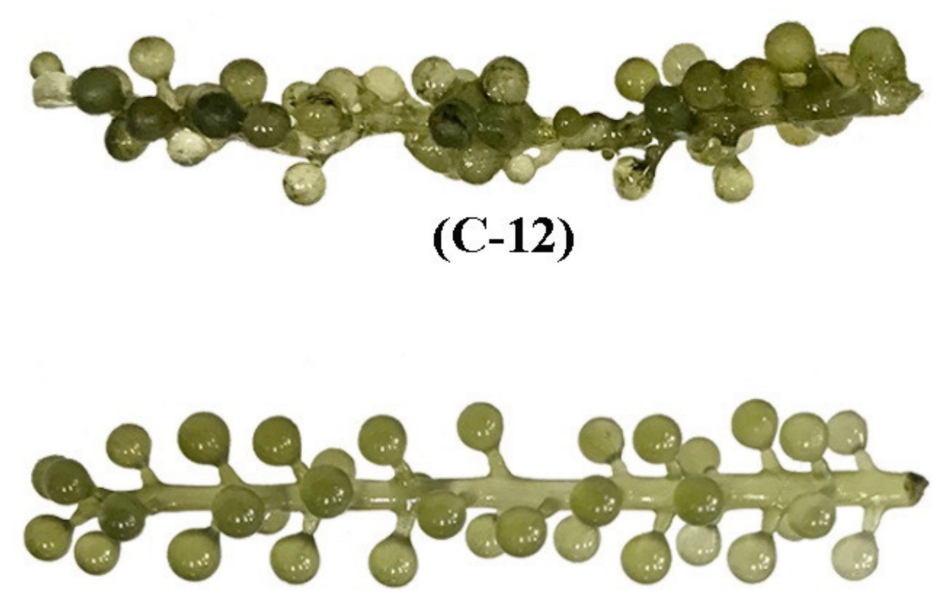

(A-12)

Figure 7. The appearance of seagrapes during post-harvest storage. The abbreviation of letters; $C$ for control group and A for ACEF group. The abbreviation of numbers; 0 for day- 0,3 for day-3, 6 for day-6, 9 for day-9, and 12 for day-12.

\subsubsection{Effect of ACEF on Chlorophyll Content of Seagrape}

The oxidative stress led by ROS accumulation enhanced the seagrapes' chlorophyll degradation that confirms stressed condition depress the chlorophyll fluorescence [26,96]. Chlorophyll is the pigment photosynthesis of seagrape, which is degraded due to enzyme activities once it experiences photoinhibition $[31,57,97]$. Chlorophyll degradation in many studies is described to be caused by enzymatic reactions due to the oxidative stress condition in this study. The chlorophyll degradation in the control group is severe as the post-harvest storage lengthens. However, the ACEF group was found to prevent the high degradation in Figure 6D,E. This phenomenon may be caused by the effectivity of ACEF in interfering with the chlorophyll pigment of seagrape during treatment, primarily on the chemical bonds between the pyrrole ring and the central magnesium ions of chlorophyll. This result is similar to Zhang et al. [98] that showed a significant effect of EF that could form chlorophyll aggregated structures, thereby increasing chlorophylls' stability.

Pongsri et al. [57] described the mechanism of enzyme activities in decomposing the chlorophyll structure of the agricultural product that results in the chlorophyll content degradation. The result in this study might show a similarity to Sánchez-Vega et al. [99] to overcome the chlorophyll degradation by diminishing the chlorophyll-degrading enzymes with EF application. The movement of chlorophyll pigments $\left(\mathrm{Mg}^{2+}\right.$ in porphyrin ring and carboxyl side chain) are moving toward electrode (cathode and anode) surfaces when subjected to electric fields $[88,89]$. In this study, ACEF may be slowing the phytol removal, the production of ROS, and the migration of pheophytin in replacing the $\mathrm{Mg}^{2+}$ during the chlorophyll decomposition mechanism. The ACEF treatment in this study might have a better performance compared to the application of diethyldithiocarbamic acid by Fang et al. [100] and micro-vacuum storage by Sun and Li [77]. This study showed a significant effect in inhibiting the chlorophyll degradation of seagrape during 9 days of storage (Figure 7).

\subsection{Principal Component Analysis (PCA) on Physicochemical Quality of Seagrape}

PCA is an advanced tool of statistical analysis to study similarities and patterns in the data among samples that remain unclear, which can easily interpret the grouping relationships on multivariate data of bioactive compounds or functional properties in foods [101]. The PCA results in Figure 8 show a higher weight of covariance matrices that allocate up to $94.01 \%$ of the variability of the data among the analyzed variables. The correlation matrix table shows that the physicochemical variables are significantly different at $p<0.05$, which indicates the variables have a high correlation with each other 
during post-harvest storage. As we can see from the correlation table in Figure 8, the total chlorophyll and TPC is significantly positively correlated $(r=0.939)$ that indicates the higher the chlorophyll content the higher the TPC in seagrape. The total chlorophyll and MDA is significantly negatively correlated $(r=-0.816)$ that indicates the lower the chlorophyll content the higher the MDA compound in seagrape. Furthermore, the MDA and the water loss have a significantly positively correlated $(r=0.621)$ that indicates the higher the water loss the higher the generated MDA compound on seagrape. On the other hand, TPC is significantly negatively correlated with MDA compound $(r=-0.870)$ that indicates the higher the TPC the lower the generated MDA compound as well as the water loss that occurred on seagrape. Finally, total chlorophyll and TPC have a significantly positively correlated to the water loss $(r=-0.621$ and $r=-0.658)$ that indicates the higher the water loss the higher the lower the chlorophyll and TPC of seagrape during post-harvest storage.

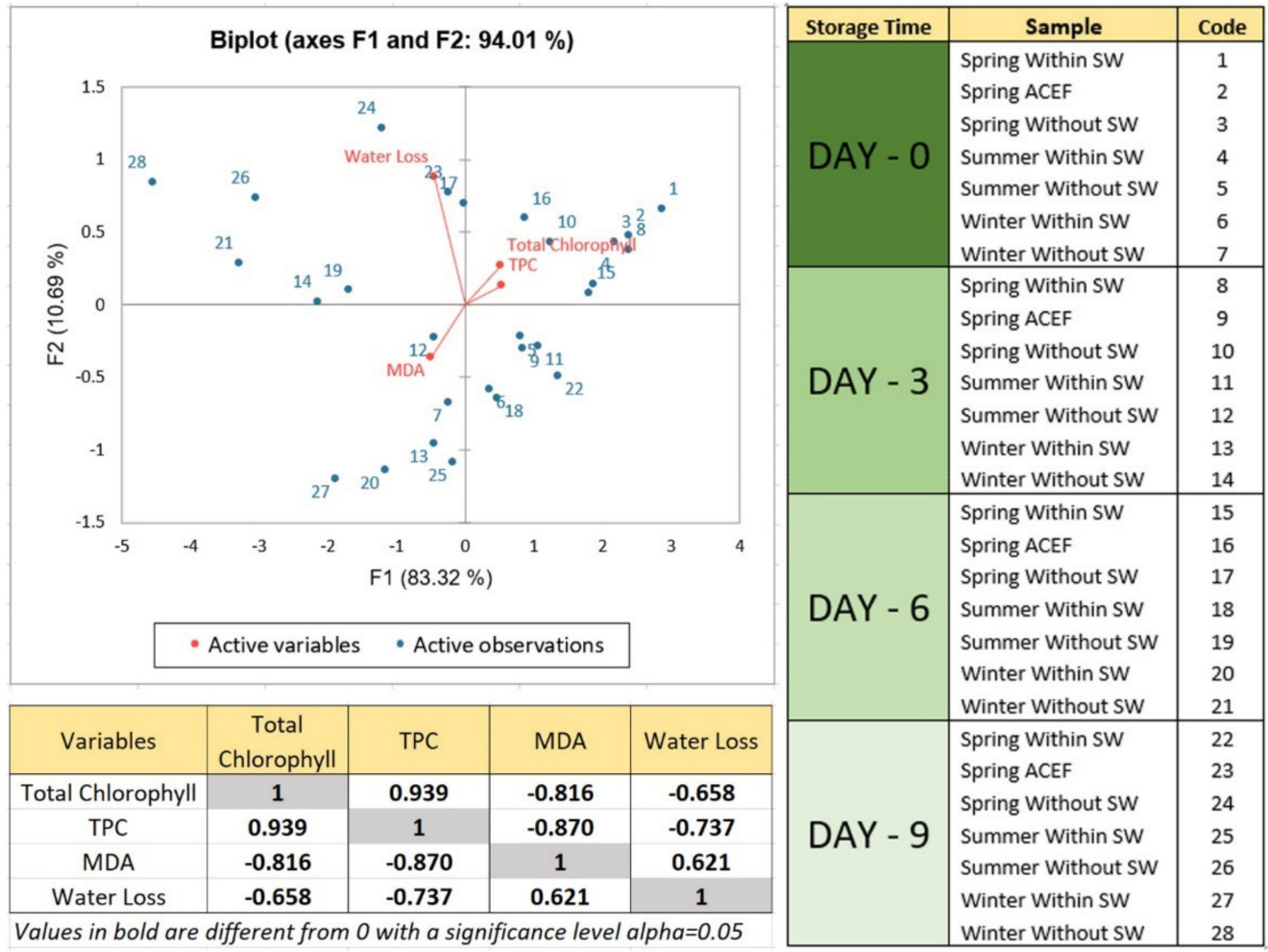

Figure 8. Principal component analysis (PCA) on physicochemical quality of seagrape during post-harvest storage.

The biplot chart in Figure 8 shows the sample variance distribution when subjected to the analyzed variables, represented by the PCA 1 dimension that covers $88.32 \%$ of the initial information. It determined positively linked variables between total chlorophyll and TPC. The individual sample that contains high TPC and chlorophyll has less MDA compound, and the sample has less chlorophyll and TPC has higher water loss. Nonetheless, some samples contain a high MDA compound and less chlorophyll and TPC have less water loss due to the difference in storage conditions. The correlation results above correspond to previous studies that have explained the relationship between each variable in this study. In summary, the aggregation of phenolic compounds is regarded as an adaptive mechanism to prevent plants against cellular oxidative stress conditions by detoxifying ROS [102,103], which are reduced during the oxidation process. The imbalance of ROS accumulation during oxidative stress conditions leads to the occurrence of photoinhibition that degrades the chlorophyll content of seagrape $[7,26,43,97,104]$. ROS also generates the MDA production to break the cell wall of seagrape that forces the occurrence of osmotic water loss during oxidative stress conditions [5,29]. 


\section{Conclusions}

The cultivation season is a vital factor in influencing the physicochemical properties of seagrape and their changes during post-harvest storage $(p<0.05)$. The results of this study show the second-order reaction in terms of the kinetics of chlorophyll degradation on seagrape cultivated in spring. The loss of chlorophyll is less than in summer and winter, indicating the spring seagrape has a better quality performance during post-harvest storage. The storage experiment results show that the seawater immersion may stabilize the seagrapes' osmotic pressure and suppress the oxidative stress, resulting in a longer shelf-life with the greater content of water, chlorophyll, phenolic, and MDA accentuation. Furthermore, this study reveals the effectiveness of ACEF as the first non-processed technology to preserve the fresh seagrape product by suppressing the ROS accumulation during oxidative stress condition. The novelty of this treatment can lower the water loss $(p<0.01)$, chlorophyll degradation $(p<0.01)$, MDA production $(p<0.01)$, and phenolic reduction $(p<0.05)$ of desiccated fresh seagrape by reaching $10-30 \%$ of inhibition, resulting in the shelf-life extension of seagrape up to 12 days of storage. The results of this study are preliminary research, and it needs to be enriched for future research in the optimization of seagrape preservation methods, especially the mechanism of EF treatment related to the metabolism pathway and enzymatic activity of seagrape during the post-harvest stage. However, this study can be used to lead the perspective of consumers in buying seagrape products and the farmer in forecasting the seagrape acceptance in the market.

Author Contributions: Conceptualization, C.-W.H. and A.S.S.; methodology, C.-W.H. and A.S.S.; software, A.S.S.; validation, A.S.S. and C.-K.C.; formal analysis, A.S.S. and C.-K.C.; investigation, C.-W.H. and A.S.S.; resources, C.-W.H.; data curation, C.-W.H. and A.S.S.; writing-original draft preparation, C.-W.H. and A.S.S.; writing-review and editing, C.-W.H., A.S.S., C.-K.C., C.-Y.H., K.-C.C., S.P.S., B.Y., F.P. and C.-T.L.; supervision, C.-W.H.; funding: C.-W.H.; project administration, C.-W.H. All authors have read and agreed to the published version of the manuscript.

Funding: This research was funded by Ministry of Science and Technology, R.O.C. Taiwan, grant number 104-2221-E-212-010-MY2; 106-2221-E-005-093-MY3.

Acknowledgments: The authors wish to thank the Ministry of Science and Technology, Republic of China (grant no. 104-2221-E-212-010 -MY2; 106-2221-E-005-093-MY3) for their financial support.

Conflicts of Interest: The authors declare no conflict of interest.

\section{References}

1. Zubia, M.; Draisma, S.G.A.; Morrissey, K.L.; Varela-Álvarez, E.; De Clerck, O. Concise review of the genus Caulerpa J.V. Lamouroux. J. Appl. Phycol. 2020, 32, 23-39. [CrossRef]

2. De Gaillande, C.; Payri, C.; Remoissenet, G.; Zubia, M. Caulerpa consumption, nutritional value and farming in the Indo-Pacific region. J. Appl. Phycol. 2017, 29, 2249-2266. [CrossRef]

3. Chaiklahan, R.; Srinorasing, T.; Chirasuwan, N.; Tamtin, M.; Bunnag, B. The potential of polysaccharide extracts from Caulerpa lentillifera waste. Int. J. Biol. Macromol. 2020, 161, 1021-1028. [CrossRef]

4. Morris, C.; Bala, S.; South, G.R.; Lako, J.; Lober, M.; Simos, T. Supply chain and marketing of sea grapes, Caulerpa racemosa (Forsskål) J. Agardh (Chlorophyta: Caulerpaceae) in Fiji, Samoa and Tonga. J. Appl. Phycol. 2014, 26, 783-789. [CrossRef] [PubMed]

5. Holzinger, A.; Karsten, U. Desiccation stress and tolerance in green algae: Consequences for ultrastructure, physiological, and molecular mechanisms. Front. Plant. Sci. 2013, 4, 1-19. [CrossRef] [PubMed]

6. Scheibe, R.; Beck, E. Drought, Desiccation, and Oxidative Stress. In Plant Desiccation Tolerance; Ecological Studies; Springer: Berlin/Heidelberg, Germany, 2011; Volume 215, pp. 209-231.

7. Terada, R.; Nakazaki, Y.; Borlongan, I.A.; Endo, H.; Nishihara, G.N. Desiccation effect on the PSII photochemical efficiency of cultivated Japanese Caulerpa lentillifera under the shipping package environment. J. Appl. Phycol. 2018, 30, 2533-2538. [CrossRef]

8. Kudaka, J.; Itokazu, K.; Taira, K.; Nidaira, M.; Okano, S.; Nakamura, M.; Iwanaga, S.; Tominaga, M.; Ohno, A. Investigation and culture of microbial contaminants of Caulerpa lentillifera (Sea Grape). J. Food Hyg. Soc. Jpn. 2008, 49, 11-15. [CrossRef]

9. Anantpinijwatna, A.; Nuntamongkol, S.; Tudkesorn, B.; Sukchoy, O.; Deetae, P. The kinetic model and temperature effect of Caulerpa lentillifera drying process. AIP Conf. Proc. 2018, 2026, 020036.

10. Lapong, I.; Paul, N.; Reza, A. Evaluation of the brine preservation method of sea grapes (Caulerpa lentillifera) as a commercial product. Mar. Chim. Acta 2019, 20, 45-50. 
11. Djaeni, M.; Sari, D.A. Low temperature seaweed drying using dehumidified air. Procedia Environ. Sci. 2015, 23, 2-10. [CrossRef]

12. Lapong, I.; Paul, N.; Reza, A. Characterization of sea grape (Caulerpa lentillifera) from Vietnamese company's products. Mar. Chim. Acta 2019, 2, 51-57.

13. Dalvi-Isfahan, M.; Hamdami, N.; Le-Bail, A.; Xanthakis, E. The principles of high voltage electric field and its application in food processing: A review. Food Res. Int. 2016, 89, 48-62. [CrossRef]

14. Muthukumaran, A.; Orsat, V.; Bajgai, T.R.; Raghavan, G.S.V. Effect of high electric field on food processing. In Novel Food Processing: Effects on Rheological and Functional Properties; Ahmed, J., Ramaswamy, H.S., Kasapis, S., Boye, J.I., Eds.; CRC Press: Boca Raton, FL, USA, 2010; pp. 35-46.

15. Ko, W.C.; Yang, S.Y.; Chang, C.K.; Hsieh, C.W. Effects of adjustable parallel high voltage electrostatic field on the freshness of tilapia (Orechromis niloticus) during refrigeration. LWT-Food Sci. Technol. 2016, 66, 151-157. [CrossRef]

16. Liu, C.E.; Chen, W.J.; Chang, C.K.; Li, P.H.; Lu, P.L.; Hsieh, C.W. Effect of a high voltage electrostatic field (HVEF) on the shelf life of persimmons (Diospyros kaki). LWT-Food Sci. Technol. 2017, 75, 236-242. [CrossRef]

17. Hsieh, C.C.; Chang, C.K.; Wong, L.W.; Hu, C.C.; Lin, J.A.; Hsieh, C.W. Alternating current electric field inhibits browning of Pleurotus ostreatus via inactivation of oxidative enzymes during postharvest storage. LWT-Food Sci. Technol. 2020, $134,110212$. [CrossRef]

18. Hsieh, C.W.; Ko, W.C. Effect of high-voltage electrostatic field on quality of carrot juice during refrigeration. LWT-Food Sci. Technol. 2008, 41, 1752-1757. [CrossRef]

19. Singh, S.P.; Singh, P. Effect of temperature and light on the growth of algae species: A review. Renew. Sustain. Energy Rev. 2015, 50, 431-444. [CrossRef]

20. Charrier, B.; Abreu, M.H.; Araujo, R.; Bruhn, A.; Coates, J.C.; De Clerck, O.; Katsaros, C.; Robaina, R.R.; Wichard, T. Furthering knowledge of seaweed growth and development to facilitate sustainable aquaculture. New Phytol. 2017, 216, 967-975. [CrossRef] [PubMed]

21. Paull, R.E.; Chen, N.J. Postharvest handling and storage of the edible red seaweed Gracilaria. Postharvest Biol. Technol. 2008, 48, 302-308. [CrossRef]

22. Seremet, L.; Botez, E.; Nistor, O.V.; Andronoiu, D.G.; Mocanu, G.D. Effect of different drying methods on moisture ratio and rehydration of pumpkin slices. Food Chem. 2016, 195, 104-109. [CrossRef]

23. Jaballi, I.; Sallem, I.; Feki, A.; Cherif, B.; Kallel, C.; Boudawara, O.; Jamoussi, K.; Mellouli, L.; Nasri, M.; Amara, I.B. Polysaccharide from a Tunisian red seaweed Chondrus canaliculatus: Structural characteristics, antioxidant activity and in vivo hematonephroprotective properties on maneb induced toxicity. Int. J. Biol. Macromol. 2019, 123, 1267-1277. [CrossRef]

24. García-Sánchez, M.; Korbee, N.; Pérez-Ruzafa, I.M.; Marcos, C.; Domínguez, B.; Figueroa, F.L.; Pérez-Ruzafa, Á. Physiological response and photoacclimation capacity of Caulerpa prolifera (Forsskål) J.V. Lamouroux and Cymodocea nodosa (Ucria) Ascherson meadows in the Mar Menor lagoon (SE Spain). Mar. Environ. Res. 2012, 79, 37-47. [CrossRef] [PubMed]

25. Nurjanah, N.; Jacoeb, A.M.; Asmara, D.A.; Hidayat, T. Phenol Component of Fresh and Boiled Sea Grapes (Caulerpa Sp.) From Tual, Maluku. Food Sci. J. 2019, 1, 31-39. [CrossRef]

26. Guo, H.; Yao, J.; Sun, Z.; Duan, D. Effect of temperature, irradiance on the growth of the green alga Caulerpa lentillifera (Bryopsidophyceae, Chlorophyta). J. Appl. Phycol. 2015, 27, 879-885. [CrossRef]

27. Molaveisi, M.; Beigbabaei, A.; Akbari, E.; Noghabi, M.S.; Mohamadi, M. Kinetics of temperature effect on antioxidant activity, phenolic compounds and color of Iranian jujube honey. Heliyon 2019, 5, e01129. [CrossRef]

28. Vidal, N.P.; Manful, C.F.; Pham, T.H.; Stewart, P.; Keough, D.; Thomas, R. MethodsX The use of XLSTAT in conducting principal component analysis (PCA) when evaluating the relationships between sensory and quality attributes in grilled foods. Methods $X$ 2020, 7, 100835. [CrossRef]

29. Kranner, I.; Beckett, R.; Hochman, A.; Nash, T.H. Desiccation-tolerance in lichens: A review. Bryologist 2008, 111, 576-593. [CrossRef]

30. Watanabe, Y.; Morikawa, T.; Mine, T.; Kawamura, Y.; Nishihara, G.N.; Terada, R. Chronological change and the potential of recovery on the photosynthetic efficiency of Pyropia yezoensis f. narawaensis (Bangiales) during the sporelings frozen storage treatment in the Japanese Nori cultivation. Phycol. Res. 2017, 65, 265-271. [CrossRef]

31. Guo, H.; Yao, J.; Sun, Z.; Duan, D. Effects of salinity and nutrients on the growth and chlorophyll fluorescence of Caulerpa lentillifera. Chin. J. Oceanol. Limnol. 2015, 33, 410-418. [CrossRef]

32. Suriati, L.; Utama, I.M.S.; Harsojuwono, B.A.; Gunam, I.B.W. Incorporating additives for stability of Aloe gel potentially as an edible coating. AIMS Agric. Food. 2020, 5, 327-336. [CrossRef]

33. Yu, Q.; Wu, W.; Tian, X.; Hou, M.; Dai, R.; Li, X. Unraveling proteome changes of Holstein beef M. semitendinosus and its relationship to meat discoloration during post-mortem storage analyzed by label-free mass spectrometry. J. Proteom. 2017, 154, 85-93. [CrossRef]

34. Hung, L.H.; Kimura, Y.; Adachi, S. Discoloration kinetics of L-ascorbyl 6-palmitate powders with various water contents. Food Sci. Technol. Res. 2007, 13, 7-12. [CrossRef]

35. Shad, Z.M.; Atungulu, G.G. Post-harvest kernel discoloration and fungi activity in long-grain hybrid, pureline and medium-grain rice cultivars as influenced by storage environment and antifungal treatment. J. Stored Prod. Res. 2019, 81, 91-99. [CrossRef]

36. Catalá, A.; Díaz, M. Editorial: Impact of lipid peroxidation on the physiology and pathophysiology of cell membranes. Front. Physiol. 2016, 7, 1-3. [CrossRef] 
37. Wang, W.J.; Wang, F.J.; Zhu, J.Y.; Sun, X.T.; Yao, C.Y.; Xu, P. Freezing tolerance of Porphyra yezoensis (Bangiales, Rhodophyta) gametophyte assessed by chlorophyll fluorescence. J. Appl. Phycol. 2011, 23, 1017-1022. [CrossRef]

38. Saito, H.; Xue, C.; Yamashiro, R.; Moromizato, S.; Itabashi, Y. High polyunsaturated fatty acid levels in two subtropical macroalgae, cladosiphon okamuranus and caulerpa lentillifera. J. Phycol. 2010, 46, 665-673. [CrossRef]

39. Nagappan, T.; Vairappan, C.S. Nutritional and bioactive properties of three edible species of green algae, genus Caulerpa (Caulerpaceae). J. Appl. Phycol. 2014, 26, 1019-1027. [CrossRef]

40. Matanjun, P.; Mohamed, S.; Mustapha, N.M.; Muhammad, K. Nutrient content of tropical edible seaweeds, Eucheuma cottonii, Caulerpa lentillifera and Sargassum polycystum. J. Appl. Phycol. 2009, 21, 75-80. [CrossRef]

41. Hao, H.; Fu, M.; Yan, R.; He, B.; Li, M.; Liu, Q.; Cai, Y.; Zhang, X.; Huang, R. Chemical composition and immunostimulatory properties of green alga Caulerpa racemosa var peltata. Food Agric. Immunol. 2019, 30, 937-954. [CrossRef]

42. Wang, Y.; Ji, S.; Dai, H.; Kong, X.; Hao, J.; Wang, S.; Zhou, X.; Zhao, Y.; Wei, B.; Cheng, S.; et al. Changes in membrane lipid metabolism accompany pitting in blueberry during refrigeration and subsequent storage at room temperature. Front. Plant Sci. 2019, 10, 829. [CrossRef]

43. Rezayian, M.; Niknam, V.; Ebrahimzadeh, H. Oxidative damage and antioxidative system in algae. Toxicol. Rep. 2019, 6, 1309-1313. [CrossRef]

44. Gaschler, M.M.; Stockwell, B.R. Lipid peroxidation in cell death. Biochem. Biophys. Res. Commun. 2017, 482, 419-425. [CrossRef]

45. Kong, W.; Liu, F.; Zhang, C.; Zhang, J.; Feng, H. Non-destructive determination of Malondialdehyde (MDA) distribution in oilseed rape leaves by laboratory scale NIR hyperspectral imaging. Sci. Rep. 2016, 6, 1-8. [CrossRef]

46. Kim, A.N.; Kim, H.J.; Chun, J.; Heo, H.J.; Kerr, W.L.; Choi, S.G. Degradation kinetics of phenolic content and antioxidant activity of hardy kiwifruit (Actinidia arguta) puree at different storage temperatures. LWT-Food Sci. Technol. 2018, 89, 535-541. [CrossRef]

47. Zhang, C.; Wang, X.; Ma, Z.; Luan, Z.; Wang, Y.; Wang, Z.; Wang, L. Removal of phenolic substances from wastewater by algae. A review. Environ. Chem. Lett. 2019, 8, 377-392. [CrossRef]

48. Duan, A.W.; Meng, F.; Lin, Y. Toxicological effects of phenol on four marine microalgae. Environ. Toxicol. Pharmacol. 2017, 52, 170-176. [CrossRef]

49. Aisyah, Y.; Rasdiansyah, M. Effect of heating on antioxidant activity in several types of vegetables. J. Teknol. Ind. Pertan. Indones. 2014, 6, 28-32.

50. Cho, M.; Kang, I.J.; Won, M.H.; Lee, H.S.; You, S. The antioxidant properties of ethanol extracts and their solvent-partitioned fractions from various green seaweeds. J. Med. Food. 2010, 13, 1232-1239. [CrossRef]

51. Matanjun, P.; Mohamed, S.; Mustapha, N.M.; Muhammad, K.; Ming, C.H. Antioxidant activities and phenolics content of eight species of seaweeds from north Borneo. J. Appl. Phycol. 2008, 20, 367-373. [CrossRef]

52. Nguyen, V.T.; Ueng, J.P.; Tsai, G.J. Proximate Composition, Total Phenolic Content, and Antioxidant Activity of Seagrape (Caulerpa lentillifera). J. Food Sci. 2011, 76, 950-958. [CrossRef]

53. Mekinić, I.G.; Skroza, D.; Šimat, V.; Hamed, I.; Čagalj, M.; Perković, Z.P. Phenolic content of brown algae (Pheophyceae) species: Extraction, identification, and quantification. Biomolecules 2019, 9, 244.

54. Monteiro, M.; Santos, R.A.; Iglesias, P.; Couto, A.; Serra, C.R.; Gouvinhas, I.; Barros, A.; Oliva-Teles, A.; Enes, P.; Díaz-Rosales, P. Effect of extraction method and solvent system on the phenolic content and antioxidant activity of selected macro- and microalgae extracts. J. Appl. Phycol. 2020, 32, 349-362. [CrossRef]

55. Paul, N.A.; Neveux, N.; Magnusson, M.; de Nys, R. Comparative production and nutritional value of "sea grapes"-the tropical green seaweeds Caulerpa lentillifera and C. racemosa. J. Appl. Phycol. 2014, 26, 1833-1844. [CrossRef]

56. Elsheery, N.I.; Cao, K.F. Gas exchange, chlorophyll fluorescence, and osmotic adjustment in two mango cultivars under drought stress. Acta Physiol. Plant. 2008, 30, 769-777. [CrossRef]

57. Pongsri, R.; Aiamla-or, S.; Srilaong, V.; Uthairatanakij, A.; Jitareerat, P. Impact of electron-beam irradiation combined with shellac coating on the suppression of chlorophyll degradation and water loss of lime fruit during storage. Postharvest Biol. Technol. 2021, 172, 111364. [CrossRef]

58. Aiamla-or, S.; Shigyo, M.; Yamauchi, N. UV-B treatment controls chlorophyll degradation and related gene expression in broccoli (Brassica oleracea L. Italica Group) florets during storage. Sci. Hortic. 2019, 243, 524-527. [CrossRef]

59. Luo, F.; Cheng, S.C.; Cai, J.H.; Wei, B.D.; Zhou, X.; Zhou, Q.; Zhao, Y.B.; Ji, S.J. Chlorophyll degradation and carotenoid biosynthetic pathways: Gene expression and pigment content in broccoli during yellowing. Food Chem. 2019, $297,124964$. [CrossRef]

60. Titlyanov, E.A.; Titlyanova, T.V. Seaweed cultivation: Methods and problems. Russ. J. Mar. Biol. 2010, 36, 227-242. [CrossRef]

61. Britton, D.; Schmid, M.; Revill, A.T.; Virtue, P.; Nichols, P.D.; Hurd, C.L.; Mundy, C.N. Seasonal and site-specific variation in the nutritional quality of temperate seaweed assemblages: Implications for grazing invertebrates and the commercial exploitation of seaweeds. J. Appl. Phycol. 2021, 33, 603-616. [CrossRef]

62. Fabrowska, J.; Messyasz, B.; Pankiewicz, R.; Wilińska, P.; Łęska, B. Seasonal differences in the content of phenols and pigments in thalli of freshwater Cladophora glomerata and its habitat. Water Res. 2018, 135, 66-74. [CrossRef]

63. Moreira, A.S.P.; da Costa, E.; Melo, T.; Sulpice, R.; Cardoso, S.M.; Pitarma, B.; Pereira, R.; Abreu, M.H.; Domingues, P.; Calado, R.; et al. Seasonal plasticity of the polar lipidome of Ulva rigida cultivated in a sustainable integrated multi-trophic aquaculture. Algal Res. 2020, 49, 101958. [CrossRef] 
64. Gosch, B.J.; Paul, N.A.; de Nys, R.; Magnusson, M. Spatial, seasonal, and within-plant variation in total fatty acid content and composition in the brown seaweeds Dictyota bartayresii and Dictyopteris australis (Dictyotales, Phaeophyceae). J. Appl. Phycol. 2015, 27, 1607-1622. [CrossRef]

65. Fariman, G.A.; Shastan, S.J.; Zahedi, M.M. Seasonal variation of total lipid, fatty acids, fucoxanthin content, and antioxidant properties of two tropical brown algae (Nizamuddinia zanardinii and Cystoseira indica) from Iran. J. Appl. Phycol. 2016, 28, $1323-1331$. [CrossRef]

66. Choo, K.S.; Snoeijs, P.; Pedersén, M. Oxidative stress tolerance in the filamentous green algae Cladophora glomerata and Enteromorpha ahlneriana. J. Exp. Mar. Biol. Ecol. 2004, 298, 111-123. [CrossRef]

67. Tưởng, L.T.; Trang, N.T.M. Optimization of early processing of grape seaweed (Caulerpa lentillifera J. Agardh, 1837) after harvested. Can. Tho Univ. J. Sci. 2016, 47, 54-61. [CrossRef]

68. Marangoni, A.G. Chlorophyll degradation in green tissues: Olives, cabbage and pickles. In Kinetic Analysis of Food Systems; Springer: Cham, Switzerland, 2017; pp. 55-63.

69. Foyer, C.H. Reactive oxygen species, oxidative signaling and the regulation of photosynthesis. Environ. Exp. Bot. 2018, 154, 134-142. [CrossRef] [PubMed]

70. Noctor, G.; Reichheld, J.P.; Foyer, C.H. ROS-related redox regulation and signaling in plants. Semin. Cell Dev. Biol. 2018, 80, 3-12. [CrossRef] [PubMed]

71. Czarnocka, W.; Karpiński, S. Friend or foe? Reactive oxygen species production, scavenging and signaling in plant response to environmental stresses. Free Radic. Biol. Med. 2018, 122, 4-20. [CrossRef] [PubMed]

72. Nofiani, R.; Hertanto, S.; Zaharah, T.A.; Gafur, S. Proximate Compositions and Biological Activities of Caulerpa lentillifera. Molekul 2018, 13, 141-147. [CrossRef]

73. Jespersen, D.; Zhang, J.; Huang, B. Chlorophyll loss associated with heat-induced senescence in bentgrass. Plant Sci. 2016, 249, 1-12. [CrossRef] [PubMed]

74. Buvé, C.; Kebede, B.T.; De Batselier, C.; Carrillo, C.; Pham, H.T.T.; Hendrickx, M.; Grauwet, T.; Van Loey, A. Kinetics of colour changes in pasteurised strawberry juice during storage. J. Food Eng. 2018, 216, 42-51. [CrossRef]

75. Sonar, C.R.; Rasco, B.; Tang, J.; Sablani, S.S. Natural color pigments: Oxidative stability and degradation kinetics during storage in thermally pasteurized vegetable purees. J. Sci. Food Agric. 2019, 99, 5934-5945. [CrossRef] [PubMed]

76. Wibowo, S.; Grauwet, T.; Santiago, J.S.; Tomic, J.; Vervoort, L.; Hendrickx, M.; Van Loey, A. Quality changes of pasteurised orange juice during storage: A kinetic study of specific parameters and their relation to colour instability. Food Chem. 2015, 187, 140-151. [CrossRef]

77. Sun, Y.; Li, W. Effects the mechanism of micro-vacuum storage on broccoli chlorophyll degradation and builds prediction model of chlorophyll content based on the color parameter changes. Sci. Hortic. 2017, 224, 206-214. [CrossRef]

78. Aryanti, N.; Nafiunisa, A. Extraction, characterization and degradation of chlorophyll from Suji Leaves (Pleomele angustifolia). Orient. J. Chem. 2017, 33, 3185-3190. [CrossRef]

79. Nayak, P.K.; Mohan, C.C.; Radhakrishnan, K. Effect of microwave pretreatment on the color degradation kinetics in mustard greens (Brassica juncea). Chem. Eng. Commun. 2018, 205, 1261-1273. [CrossRef]

80. Benlloch-Tinoco, M.; Kaulmann, A.; Corte-Real, J.; Rodrigo, D.; Martínez-Navarrete, N.; Bohn, T. Chlorophylls and carotenoids of kiwifruit puree are affected similarly or less by microwave than by conventional heat processing and storage. Food Chem. 2015, 187, 254-262. [CrossRef]

81. Zhao, R.; Hao, J.; Xue, J.; Liu, H.; Li, L. Effect of high-voltage electrostatic field pretreatment on the antioxidant system in stored green mature tomatoes. J. Sci. Food Agric. 2011, 91, 1680-1686. [CrossRef]

82. Contreras-Porcia, L.; Thomas, D.; Flores, V.; Correa, J.A. Tolerance to oxidative stress induced by desiccation in Porphyra columbina (Bangiales, Rhodophyta). J. Exp. Bot. 2011, 62, 1815-1829. [CrossRef] [PubMed]

83. Cao, M.; Gao, Q. Effects of high-voltage electric field treatment on physicochemical properties of potato starch. J. Food Meas. Charact. 2019, 13, 3069-3076. [CrossRef]

84. Hu, Y.H.; Chen, C.M.; Xu, L.; Cui, Y.; Yu, X.Y.; Gao, H.J.; Wang, Q.; Liu, K.; Shi, Y.; Chen, Q.X. Postharvest application of 4-methoxy cinnamic acid for extending the shelf life of mushroom (Agaricus bisporus). Postharvest Biol. Technol. 2015, 104, 33-41. [CrossRef]

85. Xu, D.; Xiao, Y.; Pan, H.; Mei, Y. Toxic effects of tetracycline and its degradation products on freshwater green algae. Ecotoxicol. Environ. Saf. 2019, 174, 43-47. [CrossRef] [PubMed]

86. Zhang, F.; Yao, X.; Sun, S.; Wang, L.; Liu, W.; Jiang, X.; Wang, J. Effects of mesotrione on oxidative stress, subcellular structure, and membrane integrity in Chlorella vulgaris. Chemosphere 2020, 247, 125668. [CrossRef]

87. Meng, D.M.; Zhang, Y.X.; Yang, R.; Wang, J.; Zhang, X.H.; Sheng, J.P.; Wang, J.P.; Fan, Z.C. Arginase participates in the methyl jasmonate-regulated quality maintenance of postharvest Agaricus bisporus fruit bodies. Postharvest Biol. Technol. 2017, 132, 7-14. [CrossRef]

88. Tavakoli, A.; Sahari, M.A.; Barzegar, M.; Ahmadi Gavlighi, H. Optimization of high voltage electric field as a novel non-thermal method of sunflower oil neutralization. Sep. Purif. Technol. 2019, 211, 430-437. [CrossRef]

89. Abedi, E.; Amiri, M.J.; Sahari, M.A. Kinetic, isotherm and thermodynamic investigations on adsorption of trace elements and pigments from soybean oil using high voltage electric field-assisted bleaching: A comparative study. Process Biochem. 2020, 91, 208-222. [CrossRef] 
90. Bensalem, S.; Pareau, D.; Cinquin, B.; Français, O.; Le Pioufle, B.; Lopes, F. Impact of pulsed electric fields and mechanical compressions on the permeability and structure of Chlamydomonas reinhardtii cells. Sci. Rep. 2020, 10, 1-11. [CrossRef] [PubMed]

91. Yan, M.; Yuan, B.; Xie, Y.; Cheng, S.; Huang, H.; Zhang, W. Postharvest Biology and Technology Improvement of postharvest quality, enzymes activity and polyphenoloxidase structure of postharvest Agaricus bisporus in response to high voltage electric field. Postharvest Biol. Technol. 2020, 166, 111230. [CrossRef]

92. Yamauchi, N. Postharvest Chlorophyll Degradation and Oxidative Stress. In Abiotic Stress Biology in Horticultural Plants; Kanayama, Y., Kochetov, A., Eds.; Springer: Tokyo, Japan, 2015; pp. 101-113.

93. Sairam, R.K.; Tyagi, A. Physiology and molecular biology of stress tolerance in plants. In Current Science; Current Science Association: Bangalore, India, 2004; Volume 86, pp. 407-421.

94. Jiang, T.; Jahangir, M.M.; Jiang, Z.; Lu, X.; Ying, T. Influence of UV-C treatment on antioxidant capacity, antioxidant enzyme activity and texture of postharvest shiitake (Lentinus edodes) mushrooms during storage. Postharvest Biol. Technol. 2010, 56, 209-215. [CrossRef]

95. Petriccione, M.; Pagano, L.; Forniti, R.; Zampella, L.; Mastrobuoni, F.; Scortichini, M.; Mencarelli, F. Postharvest treatment with chitosan affects the antioxidant metabolism and quality of wine grape during partial dehydration. Postharvest Biol. Technol. 2018, 137, 38-45. [CrossRef]

96. Guidi, L.; Lo Piccolo, E.; Landi, M. Chlorophyll fluorescence, photoinhibition and abiotic stress: Does it make any difference the fact to be a C3 or C4 species? Front. Plant Sci. 2019, 10, 1-11. [CrossRef]

97. Kudoh, H.; Sonoike, K. Irreversible damage to photosystem I by chilling in the light: Cause of the degradation of chlorophyll after returning to normal growth temperature. Planta 2002, 215, 541-548. [CrossRef] [PubMed]

98. Zhang, Z.H.; Wang, L.H.; Zeng, X.A.; Han, Z.; Wang, M.S. Effect of pulsed electric fields (PEFs) on the pigments extracted from spinach (Spinacia oleracea L.). Innov. Food Sci. Emerg. Technol. 2017, 43, 26-34. [CrossRef]

99. Sánchez-Vega, R.; Elez-Martínez, P.; Martín-Belloso, O. Effects of High-Intensity Pulsed Electric Fields Processing Parameters on the Chlorophyll Content and Its Degradation Compounds in Broccoli Juice. Food Bioprocess Technol. 2014, 7, 1137-1148. [CrossRef]

100. Fang, H.; Luo, F.; Li, P.; Zhou, Q.; Zhou, X.; Wei, B.; Cheng, S.; Zhou, H.; Ji, S. Potential of jasmonic acid (JA) in accelerating postharvest yellowing of broccoli by promoting its chlorophyll degradation. Food Chem. 2019, 309, 125737. [CrossRef] [PubMed]

101. Granato, D.; Santos, J.S.; Escher, G.B.; Ferreira, B.L.; Maggio, R.M. Use of principal component analysis (PCA) and hierarchical cluster analysis (HCA) for multivariate association between bioactive compounds and functional properties in foods: A critical perspective. Trends Food Sci. Technol. 2018, 72, 83-90. [CrossRef]

102. Gao, H.; Zhang, Z.; Lv, X.; Cheng, N.; Peng, B.; Cao, W. Postharvest Biology and Technology Effect of 24-epibrassinolide on chilling injury of peach fruit in relation to phenolic and proline metabolisms. Postharvest Biol. Technol. 2016, 111, $390-397$. [CrossRef]

103. Sun, C.; Jin, L.; Cai, Y.; Huang, Y.; Zheng, X.; Yu, T. L-Glutamate Treatment enhances disease resistance of tomato fruit by inducing the expression of glutamate receptors and the accumulation of amino acids L -Glutamate. Food Chem. 2019, 293, 263-270. [CrossRef] [PubMed]

104. Takahashi, S.; Murata, N. How do environmental stresses accelerate photoinhibition? Trends Plant Sci. 2008, 13, 178-182. [CrossRef] 